Edward Michael Brady

\title{
Aggregate Brazilian Mutual Fund Stockholdings and Asset Returns
}

Dissertação de Mestrado

Dissertation presented to the Programa de Pós-Graduação em Macroeconomia e Finanças of the Departamento de Economia, PUC-Rio, in partial fulfillment of the requirements for the degree of Mestre em Macroeconomia e Finanças.

Orientador: Prof. Ruy Monteiro Ribeiro 
Edward Michael Brady

\section{Aggregate Brazilian Mutual Fund Stockholdings and Asset Returns}

Dissertation presented to the Programa de Pós-Graduação em Macroeconomia e Finanças of the Departamento de Economia, PUC-Rio, in partial fulfillment of the requirements for the degree of Mestre em Macroeconomia e Finanças. Approved by the following Examination Committee.

Prof. Ruy Monteiro Ribeiro

Advisor

Departamento de Economia - PUC-Rio

Prof. Marco Antonio Cesar Bonomo

Insper

Prof. Walter Novaes Filho Departamento de Economia - PUC-Rio

Rio de Janeiro, September 2, 2019 
All rights reserved. The partial or total reproduction of this work is prohibited without the authorization of the university, the author and the advisor.

\section{Edward Michael Brady}

B.S.B.A., Georgetown University, 2008.

Brady, Edward Michael

Aggregate brazilian mutual fund stockholdings and asset returns / Edward Michael Brady ; advisor: Ruy Monteiro Ribeiro. - 2019.

53 f. : il. color. ; $30 \mathrm{~cm}$

Dissertação (mestrado)-Pontifícia Universidade Católica do Rio de Janeiro, Departamento de Economia, 2019.

Inclui bibliografia

1. Economia - Teses. 2. Fundos de Investimento. 3. Retorno excedente. 4. Short Interest. 5. Gestão Ativa. I. Ribeiro, Ruy Monteiro. II. Pontifícia Universidade Católica do Rio de Janeiro. Departamento de Economia. III. Título. 


\section{Acknowledgements}

First, I want to thank my wife Renata for all of the support, serenity and love.

I am extremely grateful to the professors for an inspiring couple of years, especially my dissertation advisor Ruy Monteiro Ribeiro, whose understanding and patience made this dissertation possible.

I am thankful to my parents and family who have always stressed the importance of hard work and curiosity.

Lastly, I want to thank my fellow students for their encouragement and friendship. 


\section{Abstract}

Brady, Edward Michael; Ribeiro, Ruy Monteiro (Advisor). Aggregate Brazilian Mutual Fund Stockholdings and Asset Returns. Rio de Janeiro, 2019. 53p. Dissertação de Mestrado - Departamento de Economia, Pontifícia Universidade Católica do Rio de Janeiro.

This study aims to investigate whether there is a relationship between aggregate Brazilian mutual fund positions and past, concurrent, and future stock performance. Using monthly fund portfolio data for 30.416 funds between 2006 and 2018 and market data for 84 stocks, several panel data regressions were ran to test the correlation between stock total returns and both the level and change in mutual fund aggregate long and short positions. In addition, the data was used in testing a long-short investing strategy in which stocks with high fund ownership indicators are purchased and stocks with low fund ownership indicators are sold.

\section{Keywords}

Mutual Funds; Excess Return; Short Interest; Active Management 


\section{Resumo}

Brady, Edward Michael; Ribeiro, Ruy Monteiro (Orientador). Posições Agregadas em Ações de Fundos Brasileiros e Retornos de Ativos. Rio de Janeiro, 2019. 53p. Dissertação de Mestrado - Departamento de Economia, Pontifícia Universidade Católica do Rio de Janeiro.

Este estudo objetiva investigar se existe uma relação entre posições agregadas de fundos de investimento brasileiros e o desempenho passado, presente e futuro das ações. Utilizando dados mensais das carteiras de 30.416 fundos entre 2006 e 2018 e dados de mercado de 84 ações, diversas regressões com dados em painel foram feitas para testar a correlação entre retornos totais das ações e o nível e a mudança de posições compradas e vendidas. Além disso, os dados foram utilizados para testar uma estratégia long-short de investimento segundo a qual as ações que ocupam posições altas nos fundos são compradas e as ações com baixas posições são vendidas.

\section{Palavras-chave}

Fundos de Investimento; Retorno Excedente; Short Interest; Gestão Ativa 


\section{Table of Contents}

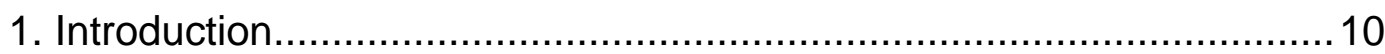

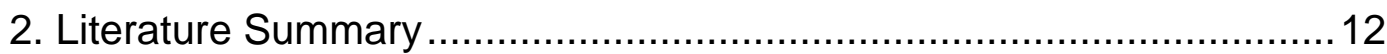

2.1. Institutional Ownership and Past Asset Returns ..........................12

2.2. Institutional Ownership and Contemporaneous Asset Returns ......13

2.3. Institutional Ownership and Future Asset Returns ......................... 14

2.4. Institutional Investors and Asset Liquidity ................................... 16

2.5. Institutional Investors and Short Interest .................................... 17

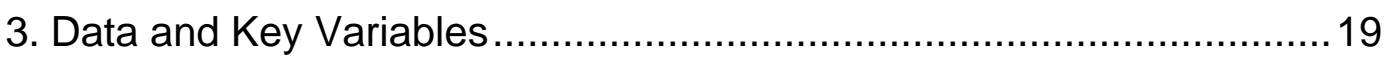

3.1. Data Sources and Description...................................................19

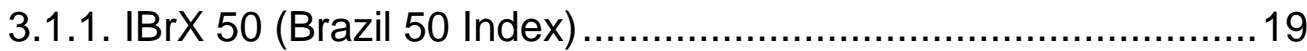

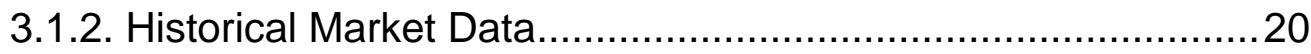

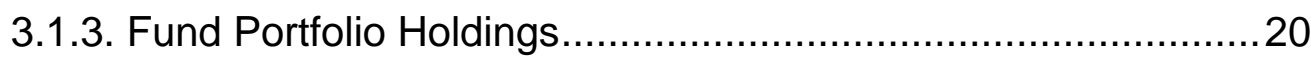

3.2. Key Measures of Aggregate Fund Holdings................................21

3.2.1. Aggregate Fund Holdings as \% of Market Cap......................21

3.2.2. Aggregate Fund Holdings as Multiple of ADTV .......................22

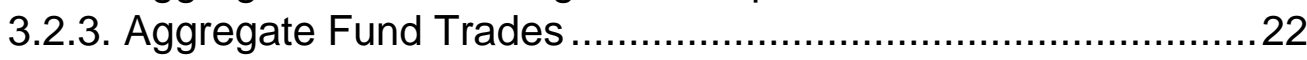

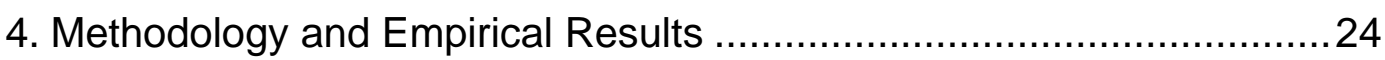

4.1. Regression Analysis Models and Results ..................................24

4.1.1. Excess Returns as a Function of Fund Holdings ....................24

4.1.2. Excess Returns as a Function of Fund Long and Fund Short

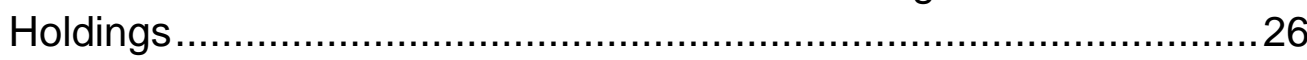

4.2. Backtesting: Returns from Theoretical Long-Short Portfolio ..........27

4.2.1. Backtest: Fund Variables as \% of Market Cap.........................28

4.4.2. Backtest: Fund Variables as Mutilple of ADTV .......................29

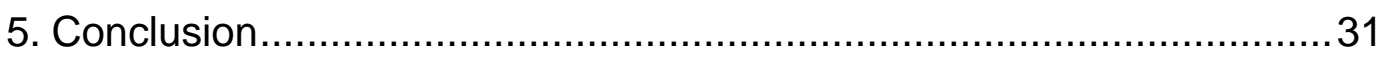

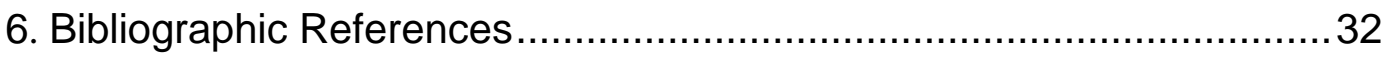

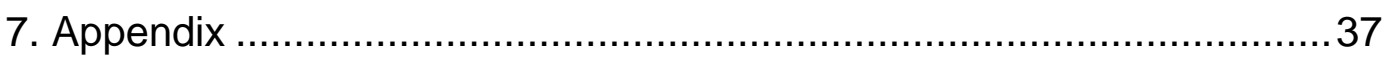




\section{List of Figures}

Figure 1: Brazilian Investment Fund Industry: Total Assets Under Management and Number of Investment Funds (December 2000 - June 2019)

Figure 2: Accumulated Returns Utilizing Fund Holdings as \% of Market Cap. Variables

Figure 3: Accumulated Returns Utilizing Fund Trades as \% of Market Cap. Variables

Figure 4: Accumulated Returns Utilizing Fund Holdings as Multiple of ADTV Variables....

Figure 5: Accumulated Returns Utilizing Fund Trades as Multiple of ADTV Variables 


\section{List of Tables}

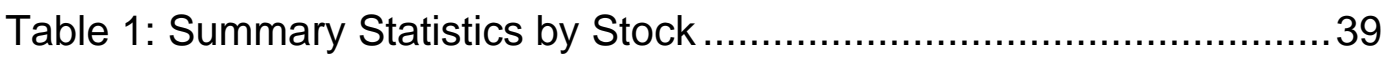

Table 2: Summary Statistics by Year ………………........................ 42

Table 3: Regression Results: Excess Returns as Function of Fund

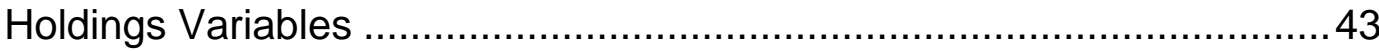

Table 4: Regression Results: Excess Returns as Function of Fund Long and Short Holdings (and Trades) .......................................................4 44

Table 5: Backtest: Fund Holdings as \% of Market Cap. ..........................45

Table 6: Backtest: Fund Trades as \% of Market Cap.............................46

Table 7: Backtest: Fund Holdings as Multiple of ADTV ...........................47

Table 8: Backtest: Fund Trades as Multiple of ADTV ..............................48 


\section{1. \\ Introduction}

Globally, the mutual fund industry is highly influential with over \$ 50 trillion in assets under management spread over 119 thousand funds, according to the Investment Company Institute. In Brazil, the investment fund industry has grown to 17,952 funds with over $\mathrm{R} \$ 5.6$ trillion in assets under management at the end of June 2019, according to ANBIMA, the Brazilian Financial and Capital Markets Association (Figure 1).

Due to the enormity of the industry and its potential influence on the financial markets and security prices, it is a subject of extensive academic debate. One area of particular interest is the relation between institutional investors and asset performance. In this paper we will use the term "fund flows" to describe the allocation and withdrawal of investment to and from investment funds. The term "fund holdings" will be used to describe the investments held by investment funds, while "fund trades", will be used to describe the investments made during the period by investment funds.

Research within the field encompasses a broad swath of topics. Warther (1995), Goetzmann and Massa (2003), Edelen and Warner (2001), and Cha and Kim (2010) discuss the relation between aggregate fund flows and market-wide returns. Ippolito (1992) and Hendricks, Patel, and Zeckhauser (1990) touch upon the relation between individual fund flows and individual fund performance. Frazzini and Lamont (2008) focuses on the relation between individual fund flows and stock performance.

An area of intense interest is the relation between individual asset returns and fund holdings and fund trades. Various papers have explored whether institutional investors employ momentum or trend-following strategies, whether fund trades create price pressures and whether institutional investors have stock picking abilities or informational advantages.

This study attempts to further understand the relation between individual asset returns and fund holdings and fund trades using data from the Brazilian investment fund industry. Similar to Chen, Jegadeesh and Wermers (2000), we explore the relation between asset returns and aggregate fund holdings and the relation between asset returns and aggregate fund trades. 
This paper adds to the existing literature in a number of ways. First, Brazilian investment funds are required to report portfolio holdings on a monthly basis. Due to this higher level of transparency within the Brazilian financial markets, the analysis is able to utilize higher frequency portfolio data compared to the quarterly portfolio holdings data provided by $13 \mathrm{~F}$ filings in the US market. Secondly, the portfolio data reported by the Brazilian investment funds includes information regarding both long and short positions, allowing us to isolate both measures on an aggregate basis. Finally, we introduce a measure of aggregate fund holdings which takes into account the level of trading liquidity of the individual assets.

The results of our analysis suggests that Brazilian institutional investors have stock-picking abilities and are correctly able to identify stocks which will underperform. Aggregate fund short holdings are positively correlated with negative future excess returns. In addition, Brazilian institutional investors appear to use trend-following strategies when implementing short positions. Utilizing fund holdings as a percentage of asset trading liquidity, we find that liquidity is also an important factor for institutional investors when considering the size of their positions.

We organize the paper as follows. Section 2 provides an overview of the existing literature on the relation between institutional ownership and asset returns. Section 3 summarizes the data and key measures utilized. Section 4 presents our quantitative analysis and results and Section 5 concludes. 


\section{2. \\ Literature Summary}

Numerous studies have investigated the relationship between institutional ownership and asset returns. We segregate this literature by asset return intervals to simplify the discussion. In section 2.1 we discuss the relation between institutional investment allocations and past asset returns and momentum investing strategies. We summarize in section 2.2 the literature on institutional investor herding and contemporaneous price effects and the possible causes of observed price effects. In section 2.3 we review the relationship between institutional investors and future asset returns and explore the stock-picking abilities of mutual fund managers.

In addition, section 2.4 recaps the effect liquidity has on institutional investor allocations. Lastly, in section 2.5 we discuss the relation between short interest and asset returns.

\section{1. Institutional Ownership and Past Asset Returns}

Momentum investing strategies, which are also known as trend-following or positive feedback trading strategies, involve buying assets that previously experienced positive returns and selling assets that previously experienced negative returns. Many studies have found evidence of momentum strategies among institutional investors.

Cai and Zheng (2004) show positive correlation between stocks with heavy institutional buying (selling) and positive (negative) returns over the previous twelve months. In addition, Nofsinger and Sias (1999) show a positive correlation between changes in institutional ownership and lag returns. Griffin, Harris and Topaloglu (2001), using daily NASDAQ data, show that there is a correlation between past stock returns and institutional trading.

Choe, Kho and Stulz (1999), studying the role of foreign investors during the 1997 economic crisis, find that both Korean and foreign institutional investors engage in trend-following behavior.

Froot, O’Connell and Seasholes (2001) find positive correlation between international net portfolio flows and lagged equity returns, suggesting that international investors display trend-following behavior. 
Grinblatt, Titman and Wermers (1995) show that mutual fund managers pursue momentum strategies, buying stocks that were past winners. Grinblatt and Keloharju (2000), using data from Finland, show that foreign institutional investors pursue momentum strategies, buying past winners and selling past losers, while Finnish households and Finish institutional investors pursue a contrarian strategy, buying past losers and selling past winners for individual stocks.

Looking at individual investors and using flows into and out of mutual funds, Sirri and Tuffano (1998), show that individual investors allocate based on prior period performance information. While these flows are on an individual investor level, these individual flows may explain institutional investor trades as shown in Khan Kogan Serafeim (2012) for mutual fund inflows and in Coval and Stafford (2007) for mutual fund outflows.

\section{2. Institutional Ownership and Contemporaneous Asset Returns}

Numerous studies have found a positive strong correlation between institutional investor trades and contemporaneous asset returns and explore whether this correlation is caused by institutional trade price-pressures or by herding behaviors among institutional investors. Herding, as defined by Sias (2004), occurs when a group of investors follows each other into the same assets over the same period of time. The price-pressure hypothesis, as described in Ben-Rephael, Kandel and Wohl (2011), describes how mutual fund flows create temporary price-pressure which is subsequently corrected in future periods.

Nofsinger and Sias (1999) show strong positive correlation between changes in institutional ownership and contemporaneous stock returns over the same period. Sias, Starks and Titman (2006) find evidence that the positive correlation between changes in institutional ownership and contemporaneous returns is associated with information effects (institutional investors are better informed than individuals).

Sias (2004) shows that institutional investors herd, following each other into and out of the same securities and show that despite being momentum investors the herding is more related to past institutional demand rather than past returns. Wermers (1999) finds evidence of herding in mutual fund trades and find that stocks bought by herding funds have higher contemporaneous and future returns, 
suggesting that institutional investors herd on new information that is then reflected in the prices. Grinblatt, Titman and Wermers (1995) find weak evidence that mutual funds exhibit herding behavior, buying and selling the same stocks at the same time.

Lakonishok, Shleifer and Vishny (1992) find evidence only in the smallest stocks of herding behavior among institutional investors and of positive correlation between changes in institutional holdings and contemporaneous excess returns. Choe, Kho and Stulz (1999) find that both Korean and foreign institutional investors engage in herding behavior while this behavior became less apparent during the crisis of 1997.

Griffin, Harris and Topaloglu (2001) show that there is a contemporaneous relation between changes in institutional ownership and stock returns but do not find strong evidence of institutional price pressure. Ben-Rephael, Kandel and Wohl (2011) find a high positive contemporaneous correlation between mutual fund flows and market returns and show that mutual fund flows create temporary price pressures that correct in future periods, supporting the price pressure hypothesis.

Boyer and Zheng (2002) find that quarterly stock returns are positively correlated with cash flows from mutual funds and find evidence supporting pricing pressure contributing to this positive correlation as well as evidence supporting short-term momentum trading as the source of this positive correlation.

\section{3. Institutional Ownership and Future Asset Returns}

There are numerous papers discussing whether institutional investors have the ability to outperform the market before and after expenses. Jensen (1968) shows that mutual funds do not outperform passive strategies, even when considering returns gross of expenses.

On the other hand, Chen, Jegadeesh and Wermers (2000) find evidence of stock picking skills for mutual fund managers, showing that stocks purchased by mutual funds outperform the stocks that they sell. Grinblatt and Titman (1989; 1993) examine the performance of individual stocks held by funds, and show that stocks held by mutual funds earn significantly positive risk-adjusted returns but argue that mutual fund investors cannot achieve these returns due to fund expenses. Wermers (2000), using quarterly US mutual fund portfolio data, shows that mutual 
funds hold stocks that outperform the market by 1.3 percent per year but net returns underperform by one percent due to nonstock holdings, expenses and transaction costs.

Yan and Zhang (2007) show that the positive correlation between aggregate investment fund ownership and future returns is associated with short-term investors. Gompers and Metrick (2001) show aggregate investment fund ownership is positively correlated with future returns, but changes in aggregate ownership is not. Chen, Hong and Stein (2002) test whether breadth of ownership, the number of institutional investors with long positions in a stock (breadth), is a useful indicator for forecasting future returns. They show that stocks experiencing decline in breadth of ownership subsequently underperform stocks whose breadth has increased.

Daniel, Grinblatt, Titman, Wermers (1997) show that mutual fund managers exhibit stock selection ability but show that this performance is mainly due to the characteristics of the stocks held rather than superior fundamental analysis of each security. Gruber (1996) shows that a subgroup of sophisticated mutual fund investors allocate assets to funds that go on to earn positive risk adjusted returns but that the average mutual fund underperforms passive market indexes. Similarly, Kosowski, Timmermann, Wermers and White (2006) find evidence of persistent performance among top mutual fund managers, suggesting stock picking ability among a select group. Alexander, Cici and Gibson (2006), differentiate between liquidity-motivated trades and valuation-motivated trades and find that mutual fund investors significantly outperform their benchmarks when making trades based on valuation rather than trading to meet liquidity requirements of the open-end funds.

Other studies try to explore the source of the institutional investor stockpicking abilities. Baker, Litov, Wacther and Wurgler (2010) show that stocks purchased by fund managers outperform stocks sold at the next earnings announcement and show that fund trades around earnings announcements account for a significant portion of the excess return generated by fund managers. Carhart (1997) finds that the short-term persistence of positive returns displayed by some fund managers is attributable to luck and not momentum strategies or stock picking abilities. Coval and Moskowitz (2001) show that institutional investors that strongly bias their holdings to local firms hold an informational advantage and earn abnormal returns in their geographically local investments and thus display a local 
stock picking ability. Similarly, Baik, Kang and Kim (2010) show that the level and change of local institutional holdings predict future stock returns and that local institutional investors earn higher excess returns around earnings announcements than nonlocal institutional investors.

\section{4 . \\ Institutional Investors and Asset Liquidity}

One of the key measures of aggregate fund holdings utilized in our study is the ratio between aggregate fund holdings and asset trading liquidity. Institutional investors take into account the relative liquidity of investments when making investment decisions. Wang (2003) argues that "given that institutions are required to stand ready to accommodate individuals' redemption and purchase orders, liquidity ranks as a top concern for their stock-picks”.

Falkenstein (1996), by regressing fund ownership (as a percentage of shares outstanding) on share liquidity (as measured by trading volume over shares outstanding), shows that mutual fund demand for a security is increasing in liquidity.

Massa and Phalippou (2005) show that portfolio liquidity is actively managed and that liquidity considerations affect the portfolio construction of US equity mutual funds. Similarly, Huang (2015) shows that fund managers actively manage the liquidity characteristics of the fund portfolio in response to changing market liquidity expectations. Yan (2008) finds evidence supporting liquidity as the determining factor in why fund size erodes performance.

One argument of liquidity being an important factor is the detrimental price effect of large relative trades for less liquid instruments. Coval and Stafford (2007) shows that mutual fund flows create pricing pressures in the securities held by the mutual funds experiencing the inflows and outflows. They also show that mutual funds incur costs when forced to liquidate illiquid investments due to investor redemptions.

Chordia (1996) shows that fund managers are required to account for liquidity risk when structuring their portfolios. Besides adjusting the liquidity profile of the portfolio assets to account for investor inflows and outflows, funds can try to manage the liquidity risk of their investors by opting for closed-end fund structures, 
including load fees or redemption fees, or actively filtering investors who match the liquidity profile required by the investment strategy.

Edelen (1999) concludes that the underperformance of mutual funds is not due to manager inability but rather is due to the indirect costs of liquidity-motivated trades due to the structure of open-end funds.

\section{5 . Institutional Investors and Short Interest}

The investment fund portfolio data set utilized in our study includes both long and short positions for each investment fund. There is extensive research between short positions, institutional investors and asset returns.

Boehmer Jones and Zhang (2008) demonstrate that short sellers are well informed and predict future stock returns and show that heavily shorted stocks significantly underperform lightly shorted stocks. In addition, they show that institutional short sales are the most informative and that the price effects are permanent, suggesting that short sellers do not manipulate the prices to achieve these returns.

Akbas, Boehmer, Erturk, Sorescu (2017) show that short interest levels predict future stock returns due to the fact that short sellers are better informed and are able to anticipate future fundamental events such as negative earnings surprises or analyst downgrades.

Desai, Ramesh, Thiagarajan, and Balachandran (2002), using NASDAQ stocks, show that firms with high short interest experience future negative abnormal returns. In addition, they demonstrate that increases in short interest are negatively correlated with future abnormal returns.

Diether, Lee, and Werner (2008) show that short sellers correctly predict future negative abnormal returns and increase price efficiency. Similarly, Saffi and Sigurdsson (2010) demonstrate the importance of short selling for price efficiency and market liquidity.

Jiao, Massa and Zhang (2016) demonstrate that opposite changes in short interest and fund holdings is associated with informed demand and predicts future returns. 
Christophe, Ferri and Angel (2004) demonstrate that short sellers are informed traders and front-run analyst downgrades, and suggest that this informational edge comes from insider "tipping”.

Dechow, Hutton, Meulbroek and Sloan (2001) demonstrate that short-sellers use fundamental information to take short positions in overpriced stocks.

Asquith, Pathak and Ritter (2005), using institutional ownership as a proxy for stock lending supply, show that the relationship between high short interest and abnormal lower stock returns is higher for short-sale constrained stocks.

As documented in Lamont (2012), short selling costs include interest paid for borrowing shares, increased margin requirements, and the transaction costs of implementing the trade. Short-selling risks include early recall of borrowed shares, the asymmetrical pricing risks of the security, lawsuits, regulation changes, and short squeezes. 


\section{3. \\ Data and Key Variables}

\section{1.}

\section{Data Sources and Description}

We obtained the data used in our study from three principal sources:

1. Securities and Exchange Commission of Brasil ("CVM"): CVM is the principal regulating authority of the financial markets in Brazil and is responsible for regulating capital markets and capital market participants, including financial exchanges, publicly traded companies, investment funds and investors.

2. B3 S.A. - Brasil, Bolsa, Balcão (“B3”): B3 is Brazil’s largest financial market infrastructure company, and the principal stock exchange in Brazil.

3. Economatica: a financial information provider focused on the Latin American market.

\subsection{1. IBrX 50 (Brazil 50 Index)}

We limited our analysis to ordinary shares and preferential shares which were components of the IBrX-50 Index for at least 24 months during the period of analysis (January 2006 - December 2018).

The IBrX-50 Index is a total return index designed to measure average stock performance of the 50 most actively traded and most representative stocks of the Brazilian stock market. The index components are weighted by the market value of the stock's free float. We obtained IBrX-50 component data from B3. The sample of assets in our analysis includes 84 stocks, of which 49 are ordinary shares and 35 are preferential shares. The complete list of the stocks included in our analysis and associated descriptive statistics can be found in Tables 1 and 2.

In addition, we obtained IBrX-50 end of month pricing data from B3, which we used to calculate subperiod returns of the index throughout the period of analysis. 


\subsection{2.}

\section{Historical Market Data}

For each of the 84 stocks included in our analysis, we obtained historical daily prices, daily transaction volume and quote multipliers between January 2005 and June 2019 (inclusive) from B3.

Historically in Brazil, stock prices were often listed as a price per group of shares (often 10, 100 or 1,000 shares). Using the quote multipliers, we adjusted the historical prices to calculate historical price per share for each stock at the end of each month between January 2005 and June 2019 (inclusive).

Using the daily transaction volume obtained from B3, we calculated the average daily trading volume over three month periods (“ADTV”) for each stock.

From Economatica, we obtained historical shares outstanding data for each stock and historical stock split information between January 2006 and December 2018 (inclusive).

In addition, we obtained adjusted pricing data for each of the stocks in our analysis from Economatica. Using adjusted pricing data, we calculated 1-month, 2month, 3-month, 6-month and 12-month subperiod returns for each of the stocks included in our analysis. Economatica adjusts for cash and stock dividends, stock splits, reverse splits, spinoffs, rights issues and capital reductions. More details about the adjustment factor for each type of corporate action can be found in appendix 1.

\subsection{3.}

\section{Fund Portfolio Holdings}

We obtained monthly portfolio holdings data for all Brazilian investment funds, between January 2006 and December 2018 (inclusive), from CVM, through CVM's Open Data Portal. Investment funds in Brazil are obligated to report their end of month portfolio holdings to the CVM on a monthly basis but can choose to postpone the public disclosure of this portfolio holding information for three 
months. This monthly reporting obligation is the principal advantage of using Brazilian fund data, as many international studies are limited to quarterly data.

Our sample includes monthly portfolio holding data for 30,416 different investment funds over 156 months, of which 6,214 investment funds held a position in one of the 84 stocks for at least one period.

Using our fund portfolio database, we calculated the monthly aggregate market value of long, short and net positions of Brazilian investment funds in each of the 84 stocks included in the analysis.

\section{2.}

\section{Key Measures of Aggregate Fund Holdings}

The portfolio holdings data was used to find aggregate positions held by investment funds in each stock included in our analysis. Using this data, we calculated two key measures of aggregate fund holdings and aggregate fund trades, described in the following subsections.

\subsection{1.}

\section{Aggregate Fund Holdings as \% of Market Cap.}

The first measure of aggregate fund holdings is the sum of shares of each security held by investment funds as a percentage of the market capitalization of each security. The formulas for long, short and net positions of this measure are

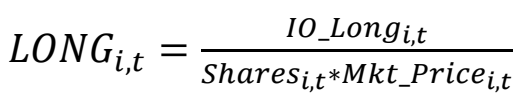

$$
\begin{aligned}
& \text { SHORT }_{i, t}=\frac{\text { IO_Short }_{i, t}}{\text { Shares }_{i, t} * \text { Mkt_Price }_{i, t}} \\
& N E T_{i, t}=L O N G_{i, t}-S H O R T_{i, t}
\end{aligned}
$$

where, $I O \_L o n g_{i, t}$ is the aggregate market value of stock $i$ held in long positions at the end of month $t$ by all investment funds and $I_{-} S_{\text {Short }}{ }_{i, t}$ is the aggregate market value of stock $i$ held in short positions at the end of month $t$ by all investment funds. Shares $_{i, t}$ is the total shares outstanding of stock $i$ at the end of month $t$ and 
$M k t_{-}$Price $_{i, t}$ is the unadjusted closing stock price of stock $i$ at the end of month $t$. The $L O N G_{i, t}$ measure is similar to the FracHoldings $s_{i, t}$ variable used by Chen, Jegadees and Wermers (2000), using market values instead of number of shares.

\subsection{2.}

\section{Aggregate Fund Holdings as Multiple of ADTV}

Due to risks of fund withdrawals on short notice, fund managers have to take into account the expected time to liquidate a position when deciding what size investment each security should represent within their portfolio. We calculated a second measure of aggregate fund holdings, which is the ratio of the aggregate investment fund holdings in each stock in relation to the ADTV of each stock. Similar to the first measure, we calculate long, short and net positions,

$$
\begin{aligned}
& \text { DaysLONG } G_{i, t}=\frac{\text { IO_Long }_{i, t}}{3 M_{-} A D T V_{i, t}} \\
& \text { DaysSHORT }_{i, t}=\frac{\text { IO_Short }_{i, t}}{3 M_{-} A D T V_{i, t}} \\
& \operatorname{DaysNET}_{i, t}=\operatorname{DaysLONG}_{i, t}-\text { DaysSHORT }_{i, t}
\end{aligned}
$$

where, $3 M_{\_} A D T V_{i, t}$ is the ADTV for stock $i$ for the three-month period ending at month $t$.

\subsection{3.}

\section{Aggregate Fund Trades}

While aggregate fund holdings can provide insight into the stock-selection abilities and process of fund managers, the change in aggregate fund holdings is useful to understand changes in investment fund manager sentiment for each security. We refer to this change in aggregate fund holdings as aggregate fund trades. Assuming managers have stock selection ability, we would expect securities with positive aggregate fund trades (aggregate fund holdings increases) between periods to have higher future returns than securities with negative aggregate fund trades (aggregate fund holdings decreases) between periods. Aggregate fund trades 
of stock $i$ during month $t$ is measured for long, short and net positions for each of the two measures as follows:

Aggregate Fund Trades as Percentage of Market Capitalization

$$
\begin{gathered}
\Delta L O N G_{i, t}=L O N G_{i, t}-L O N G_{i, t-1} \\
\Delta S H O R T_{i, t}=S H O R T_{i, t}-S H O R T_{i, t-1} \\
\Delta N E T_{i, t}=N E T_{i, t}-N E T_{i, t-1}
\end{gathered}
$$

Aggregate Fund Trades as Multiple of ADTV

$$
\begin{gathered}
\Delta \text { DaysLONG }_{i, t}=\text { DaysLONG }_{i, t}-\text { DaysLONG }_{i, t-1} \\
\Delta \text { DaysSHORT }_{i, t}=\text { DaysSHORT }_{i, t}-\text { DaysSHORT }_{i, t-1} \\
\Delta \text { DaysNET }_{i, t}=\text { DaysNET }_{i, t}-\text { DaysNET }_{i, t-1}
\end{gathered}
$$




\section{4. Methodology and Empirical Results}

\section{1. \\ Regression Analysis Models and Results}

In the following sections we describe the regression models utilized in our analysis. For each of the regressions we used random effects panel data regression analysis. We ran Hausman tests to determine whether random effects or fixed effects models were appropriate.

\subsection{1.}

\section{Excess Returns as a Function of Fund Holdings}

To test whether there exists a correlation between aggregate fund holdings or trades and security returns we ran the following random effect model regression analysis on monthly panel data:

$$
R_{i, t-1 \rightarrow t}-R_{I B r X 50, t-1 \rightarrow t}=\alpha+\beta X_{i, t}+\varepsilon_{i}+\mu_{i, t}
$$

where $R_{i, t-1 \rightarrow t}$ is the total return for security $i$ during the period $t-1 \rightarrow t$, and where $R_{I B r X 50, t-1 \rightarrow t}$ is the total return for the IBrX-50 Index during the period $t-$ $1 \rightarrow t$. Thus, the left-hand side of the equation is the excess return of security $i$ during the 1 month period ending at time $t$.

$X_{i, t}$ is the placeholder for the following independent variables: $L O N G_{i, t}$, SHORT $_{i, t}, \quad$ NET $_{i, t}, \quad$ DaysLONG $_{i, t}, \quad$ DaysSHORT $_{i, t}, \quad$ DaysNET $_{i, t}, \quad \Delta L O N G_{i, t}$, $\triangle S H O R T_{i, t}, \Delta N E T_{i, t}, \Delta$ DaysLONG $G_{i, t}, \Delta D_{\text {aysSHORT }}, t$, and $\triangle D_{\text {Days }} E T_{i, t}$.

In addition to running the regression analysis for excess returns during the contemporaneous period $(t-1 \rightarrow t)$, we repeated the regression for each of the independent variables using prior and post 1-month, 2-month, 3-month, 6-month and 12-month excess returns.

As previously explained, fund portfolio data is reported to CVM on a monthly basis. The data is reported within 10 days of the end of each month but the publication of this data in the public CVM database can be delayed until 90 days after the end of the holding period. For example, portfolio data for the end of the 
month of January must be sent to CVM by the $10^{\text {th }}$ day of February but is required to be publicly disclosed only by the beginning of May. To test if aggregate fund portfolio data has informational value once publicly available, we also ran tests for the 1-month, 2-month, 3-month, 6-month and 12-month periods starting 4 months after the aggregate funds portfolio holdings date.

The results of these regressions are found in Table 3. Panel A shows the results of the regressions in which the excess return is a function of the aggregate fund stockholding level. Looking at the aggregate fund holdings as a percentage of market cap, one can see that the regressions using the SHORT variable result in estimators with the highest statistical significance. Further analyzing these results, we find that past negative excess returns are correlated with elevated short positions for the SHORT variable, suggesting that institutional managers use trend-following or momentum strategies when implementing short positions.

Elevated short positions (SHORT) are also associated with negative excess returns in future periods, suggesting that investment fund managers who utilize short positions have stock-picking abilities or informational advantages.

In addition, elevated short positions (SHORT) are also associated with negative excess returns in the current period. Looking at the aggregate fund holdings as a multiple of ADTV we see that elevated long and net positions are associated with positive excess returns in the current period (DaysLONG and DaysNET). These results does not provide evidence of temporary price pressure since it is the level of fund holdings rather than fund trades.

The 1-month, 2-month, 3-month, and 6-month excess returns for periods beginning in month 4 (when the fund holding information is publicly available) are statistically correlated with aggregate fund position levels as a percentage of market cap (SHORT) and as a multiple of ADTV (DaysSHORT). These regressions suggest that elevated aggregate short positions are associated with negative future excess returns and that this information continues to be "useful" once publicly available.

Panel B of Table 3 shows the results of the regressions in which excess return is a function of the aggregate fund trades. An increase in aggregate long holdings as multiple of ADTV ( $\triangle$ DaysLONG) is associated with negative past excess returns. This seems to suggest that the fund managers do not employ trend- 
following strategies when implementing long positions and that they build positions in stocks whose assets have recently experienced negative returns.

\subsection{2.}

\section{Excess Returns as a Function of Fund Long and Fund Short Holdings}

To further test the relation between excess stock returns and aggregate fund holdings, we ran the following regression using: (1) the aggregate fund long variables and (2) the aggregate fund short variables.

$$
\begin{gathered}
R_{i, t-1 \rightarrow t}-R_{I B r X 50, t-1 \rightarrow t}=\alpha+\beta_{1} X_{i, t}+\beta_{2} Y_{i, t}+\varepsilon_{i}+\mu_{i, t} \\
R_{i, t-1 \rightarrow t}-R_{I B r X 50, t-1 \rightarrow t}=\alpha+\beta_{1} \Delta X_{i, t}+\beta_{2} \Delta Y_{i, t}+\varepsilon_{i}+\mu_{i, t}
\end{gathered}
$$

where $X_{i, t}$ is the placeholder for the following independent variables: $L O N G_{i, t}$ and DaysLONG $G_{i, t} . Y_{i, t}$ is the placeholder for the following independent variables: $S_{H O R T}, t$ and DaysSHORT $T_{i, t} . \Delta X_{i, t}$ is the placeholder for the following independent variables: $\Delta L O N G_{i, t}$ and $\triangle D a y s L O N G_{i, t} . \Delta Y_{i, t}$ is the placeholder for the following independent variables: $\triangle S H O R T_{i, t}$ and $\triangle D a y s S H O R T_{i, t}$.

Similar to the previous series of regressions, the excess return periods include past, current, and future excess returns.

The results of the regressions utilizing aggregate fund holding variables (formula 14 above) are found in Panel A of Table 4. Panel A1 shows the regression results using $L O N G$ and $S H O R T$ for past, concurrent, and future returns. Aggregate fund short holdings as a percentage of market cap (SHORT) are statistically correlated with past, concurrent and future negative excess returns. In Panel A2 one can see that the level of aggregate fund short holdings as a multiple of ADTV (DaysSHORT) is statistically correlated with future negative excess returns. These results seem to suggest that institutional investor short sellers have stock picking ability and correctly identify stocks which will underperform. In addition, the same holds true in periods starting in month four when all fund portfolio data is publically available. This suggests that one may be able to use publically available fund data to identify which stocks will underperform. 
The results of the regressions utilizing aggregate fund trades variables (formula 15 above) are found in Panel B of Table 4. Panel B1 shows the regression results using $\triangle L O N G$ and $\triangle S H O R T$ for past, concurrent and future returns. While the results of the regression are not statistically significant, an increase in short positions (positive aggregate fund trades) as a percentage of market capitalization is associated with negative future excess returns. Panel B2 shows similar results for the regression using $\triangle D a y s L O N G$ and $\triangle$ DaysShort. An increase in short positions as a multiple of ADTV is associated with negative future excess returns. In addition, negative past excess returns are associated with increases in long positions as a multiple of ADTV ( $\triangle$ DaysLONG).

Overall, the results of the regressions displayed in Table 4, utilizing aggregate fund long and short positions, suggest that fund managers who implement short positions have stock picking abilities for identifying which assets will underperform.

\section{2. \\ Backtesting: Returns from Theoretical Long-Short Portfolio}

For every month in our sample period, we split the stocks into three portfolios ranked by the aggregate fund variable (holdings and trades). The $1^{\text {st }}\left(3^{\text {rd }}\right)$ tercile portfolio composed of stocks with the lowest (highest) aggregate fund long positions. We then calculated the mean equal-weighted annualized excess returns of the $1^{\text {st }}$ tercile portfolio, the $3^{\text {rd }}$ tercile portfolio and a long-short portfolio ( $3^{\text {rd }}$ tercile minus $1^{\text {st }}$ tercile) for the future 1-month, 2-month, 3-month, 6-month and 12month holding periods.

In addition, we calculated the equal-weighted mean annualized excess returns of the $1^{\text {st }}$ tercile portfolio, the $3^{\text {rd }}$ tercile portfolio and a long-short portfolio ( $3^{\text {rd }}$ tercile minus $1^{\text {st }}$ tercile) for the future holding periods starting at 4 months after the aggregate funds portfolio holdings date. We repeated this process for each of the fund aggregate position variables. The results are found in the following sections. 


\subsection{1. \\ Backtest: Fund Variables as \% of Market Cap.}

Table 5 contains the results for the $L O N G$, SHORT, and NET variables (aggregate fund holdings as percentage of market cap). As can be seen in Panel B, using aggregate fund short holdings (SHORT) in the long-short strategy results in statistically significant positive returns. This statistically significant positive return is present in both the future 6-month and 12-month periods as well as the future 3month, 6-month and 12-month periods starting in month 4. The results (Panel A) of using aggregate fund long holdings ( $L O N G$ ) show similar results with reduced statistical and economic significance. The results (Panel C) of using aggregate fund net holdings (NET) are counter to what would be expected but are not statistically significant. This suggests that information is lost when netting out the long and short positions.

Figure 2 shows the accumulated returns starting in January 2006 resulting from the long-short strategy with monthly rebalancing for the $L O N G$, SHORT, and $N E T$ variables. Using 1-month holding periods and monthly rebalancing, the results of implementing the long-short strategy are economically significant when utilizing aggregate fund short holdings as a percentage of market cap (SHORT). The longshort strategy using the SHORT variable results in positive $90.5 \%$ returns at the end of the 13-year period. On the other hand, the $L O N G$ variable resulting in a meager positive $1.2 \%$ accumulated return at the end of the 13 -year period, while the NET variable results in a negative $13.2 \%$ return.

Table 6 contains the results for the $\triangle L O N G, \triangle S H O R T$, and $\triangle N E T$ variables (aggregate fund trades as percentage of market cap). Panel A of Table 6 shows the results of using aggregate fund long trades $(\triangle L O N G)$ in the long-short strategy. The mean annualized positive return from the long short strategy with holding periods of 1 -month is $12.98 \%$ and is statistically significant at the 0.001 probability level. The results (Panel B and Panel C) of using the change in the aggregate fund short position $(\triangle S H O R T)$ and the change in the aggregate fund net position $(\triangle N E T)$ show similar results with positive returns but with reduced statistical and economic significance.

Figure 3 shows the accumulated returns using the $\triangle L O N G, \triangle S H O R T$, and $\triangle N E T$ variables with monthly rebalancing. The accumulated returns of the long- 
short portfolio strategy for each of the variables is positive with the $\triangle L O N G$ variable resulting in a positive $340.7 \%$ accumulated return at the end of the 13 year period.

\subsection{2.}

\section{Backtest: Fund Variables as Mutilple of ADTV}

Table 7 contains the results using aggregate fund holdings as multiple of ADTV variables (DaysLONG, DaysSHORT, and DaysNET). The results are found in Panels A, B and C, respectively. Once again, a long-short portfolio results in economically significant returns in all periods for DaysLONG and DaysNET. Using DaysSHORT results in positive returns except for when the information becomes publically available. The average holding period returns for the long-short strategy for the 1-month, 2-month, 3-month and 6-month holding periods starting in month 4 are all negative.

The primary source of the positive returns for the long-short portfolio are the stocks purchased rather than the stocks sold short. The stocks purchased are the $3^{\text {rd }}$ tercile stocks for the DaysLONG and DaysNET variables and the $1^{\text {st }}$ tercile stocks for the DaysSHORT variable. The annualized excess returns range between $1.759 \%$ and $3.647 \%$ for the $3^{\text {rd }}$ tercile stocks (ranked by DaysLONG) and are statistically significant at the 0.001 probability level for the 6-month and 12-month holding periods starting at month 0 . In addition, the annualized excess returns are 2.195\% (significance at 0.05 probability level) for the 6-month period starting at month 4 and $1.759 \%$ (significance at the 0.01 probability level) for the 12-month period starting at month 4 . Similar results are found using the $3^{\text {rd }}$ tercile stocks for the DaysNET variable and the $1^{\text {st }}$ tercile stocks for the DaysSHORT variable. These results suggest that economically and statistically significant positive excess returns are obtainable utilizing the DaysLONG, DaysSHORT and DaysNET variables in a long-short strategy.

Figure 4 shows the accumulated returns using the DaysLONG, DaysSHORT, and DaysNET variables with monthly rebalancing from January 2006 to December 2018. The long-short portfolio strategy for the DaysSHORT variable results in a positive $109.6 \%$ accumulated return at the end of the 2018 while the DaysNET and DaysLONG variables result in positive $20.4 \%$ and negative $2.2 \%$ accumulated returns, respectively. 
Table 8 contains the results using aggregate fund trades as multiple of ADTV variables ( $\triangle$ DaysLONG, $\triangle$ DaysSHORT, and $\triangle D a y s N E T$ ). Panel C shows the results of using aggregate net fund trades as a multiple of ADTV ( $\triangle D a y s N E T$ ). The average return from the long-short portfolio is negative for the 1-month, 2month and 3-month holding periods starting at month zero (with no statistical significance) but is positive for the 2-month, 3-month, and 12-month holding periods starting at month 4 (with statistical significance at the 0.05 probability level).

Figure 5 shows the accumulated returns using the $\triangle D a y s L O N G$, $\triangle D a y s S H O R T$, and $\triangle D a y s N E T$ variables with monthly rebalancing. The accumulated returns of the long-short portfolio strategy for the $\triangle D a y s S H O R T$ variable returned the highest accumulated returns at the end of 13 years with a positive $17.3 \%$ accumulated return while the $\triangle D a y s N E T$ and $\triangle D a y s L O N G$ variables resulting in a negative accumulated returns at the end of the 13 year period. 


\section{5. \\ Conclusion}

This study aimed to investigate the relationship between aggregate Brazilian investment fund holdings and trades and asset performance for 84 different components of the $\mathrm{IBrX} 50$ index.

Utilizing publicly available fund portfolio data from 2006 to 2018, we compiled aggregate fund holdings and trades for each stock. Our fund holdings data included long, short and net positions compared to market capitalization, free float and trading liquidity. We then analyzed the relation between the aggregate fund holdings and trades and the excess returns realized by each stock in past, future and contemporaneous holding periods.

The results of our analysis suggest that information can be gleamed from the holdings and trades of Brazilian investment funds, especially when considering short positions. Aggregate short holdings of Brazilian investment funds are correlated with future negative excess returns, which suggests that Brazilian investment fund managers have stock-picking abilities and are capable of identifying underperforming assets. In addition, our analysis suggests that liquidity is an important factor for institutional investors when considering the size of their positions.

Future studies could explore segmenting portfolio data based on fund characteristics such as investment style, past investment performance, and size. In addition, differentiating trades of funds with positive flows versus the trades of funds with negative flows, one may isolate the relationship between asset returns and valuation-motivated trades. Finally, utilizing realized return in excess of expected returns (based on fundamental characteristics) rather than return in excess of the IBrX 50 index may provide more robust results. 


\section{6.}

\section{Bibliographic References}

AKBAS, F.; BOEHMER, E.; ERTURK, B.; SORESCU, S. Short Interest, Returns, and Unfavorable Fundamental Information. Financial Management, 46(2):455-486, 2017.

ALEXANDER, G.J.; CICI, G.; GIBSON, S. Does Motivation Matter When Assessing Trade Performance? An Analysis of Mutual Funds. The Review of Financial Studies, 20(1):125-150, 2006.

ASQUITH, P.; PATHAK, P. A.; RITTER, J. R. Short Interest, Institutional Ownership, and Stock Returns. Journal of Financial Economics, 78(2):243276, 2005.

BAIK, B.; KANG, J.K.; KIM, J.M. Local Institutional Investors, Information Asymmetries, and Equity Returns. Journal of Financial Economics, 97(1):81106, 2010.

BAKER, M.; LITOV, L.; WACHTER, J. A.; WURGLER, J. Can Mutual Fund Managers Pick Stocks? Evidence from their Trades Prior to Earnings Announcements. Journal of Financial and Quantitative Analysis, 45(5):11111131, 2010.

BEN-REPHAEL, A.; KANDEL, S; WOHL, A. The Price Pressure of Aggregate Mutual Fund Flows. Journal of Financial and Quantitative Analysis, 46(2):585-603, 2011.

BOEHMER, E.; JONES, C.M.; ZHANG, X. Which Shorts are Informed?. The Journal of Finance, 63(2):491-527, 2008.

BOYER, B.H.; ZHENG, L. Who Moves the Market? A Study of Stock Prices and Investment Cashflows (October 2002). AFA 2003 Washington, DC Meetings, 2003.

CAI, F.; ZHENG, L. Institutional Trading and Stock Returns. Finance Research Letters, 1(3):178-189, 2004

CARHART, M.M. On Persistence in Mutual Fund Performance. The Journal of Finance, 52(1):57-82, 1997.

CHA, H.J.; KIM, J. Stock Returns and Aggregate Mutual Fund Flows: A System Approach. Applied Financial Economics, 20(19):1493-1498, 2010.

CHEN, J.; HONG, H.; STEIN, J.C. Breadth of Ownership and Stock Returns. Journal of Financial Economics, 66(2-3):171-205, 2002. 
CHEN, H. L.; JEGADEESH, N.; WERMERS, R. The Value of Active Mutual Fund Management: An Examination of the Stockholdings and Trades of Fund Managers. Journal of Financial and Quantitative Analysis, 35(3):343368, 2000.

CHOE, H.; KHO, B. C.; STULZ, R. M. Do Foreign Investors Destabilize Stock Markets? The Korean Experience in 1997. Journal of Financial Economics, 54(2):227-264, 1999.

CHORDIA, T. The Structure of Mutual Fund Charges. Journal of Financial Economics, 41(1):3-39, 1996.

CHRISTOPHE, S. E.; FERRI, M. G.; ANGEL, J. J. Short Selling Prior to Earnings Announcements. The Journal of Finance, 59(4):1845-1876, 2004.

COVAL, J.D.; MOSKOWITZ, T.J. The Geography of Investment: Informed Trading and Asset Prices. Journal of Political Economy, 109(4):811-841, 2001.

COVAL, J.; STAFFORD, E. Asset Fire Sales (and Purchases) in Equity Markets. Journal of Financial Economics, 86(2):479-512, 2007.

DANIEL, K.; GRINBLATT, M.; TITMAN, S.; WERMERS, R. Measuring Mutual Fund Performance with Characteristic Based Benchmarks. The Journal of Finance, 52(3):1035-1058, 1997.

DECHOW, P. M.; HUTTON, A. P.; MEULBROEK, L.; SLOAN, R. G. ShortSellers, Fundamental Analysis, and Stock Returns. Journal of financial Economics, 61(1):77-106, 2001.

DESAI, H.; RAMESH, K.; THIAGARAJAN, S. R.; BALACHANDRAN, B. V. An Investigation of the Informational Role of Short Interest in the Nasdaq Market. The Journal of Finance, 57(5):2263-2287, 2002.

DIETHER, K. B.; LEE, K. H.; WERNER, I. M. Short-Sale Strategies and Return Predictability. The Review of Financial Studies, 22(2):575-607, 2008.

EDELEN, R. M. Investor Flows and the Assessed Performance of Open-End Mutual Funds. Journal of Financial Economics, 53(3):439-466, 1999.

EDELEN, R. M.; WARNER, J. B. Aggregate Price Effects of Institutional Trading: a Study of Mutual Fund Flow and Market Returns. Journal of Financial Economics, 59(2):195-220, 2001.

FALKENSTEIN, E. G. Preferences for Stock Characteristics as Revealed by Mutual Fund Portfolio Holdings. The Journal of Finance, 51(1):111-135, 1996. 
FRAZZINI, A.; LAMONT, O.A. Dumb Money: Mutual Fund Flows and the Cross-Section of Stock Returns. Journal of Financial Economics, 88(2):229322, 2008.

FROOT, K. A.; O’CONNELL, P. G.; SEASHOLES, M. S. The Portfolio Flows of International Investors. Journal of Financial Economics, 59(2):151-193, 2001.

GOETZMANN, W.N.; MASSA, M. Index Funds and Stock Market Growth. The Journal of Business, 76(1):1-28, 2003.

GOMPERS, P.A.; METRICK, A. Institutional Investors and Equity Prices. The Quarterly Journal of Economics, 116(1):229-259, 2001.

GRIFFIN, J.M.; HARRIS, J.H.; TOPALOGLU, S. The Dynamics of Institutional and Individual Trading. The Journal of Finance, 58(6):2285-2320, 2003.

GRINBLATT, M.; KELOHARJU, M. The Investment Behavior and Performance of Various Investor Types: a Study of Finland's Unique Data Set. Journal of Financial Economics, 55(1): 43-67, 2000.

GRINBLATT, M.; TITMAN, S. Mutual Fund Performance: An Analysis of Quarterly Portfolio Holdings. Journal of Business, 393-416, 1989.

GRINBLATT, M.; TITMAN, S. Performance Measurement without Benchmarks: An Examination of Mutual Fund Returns. Journal of Business, 66:47-68, 1993.

GRINBLATT, M.; TITMAN, S.; WERMERS, R. Momentum Investment Strategies, Portfolio Performance, and Herding: A Study of Mutual Fund Behavior. The American Economic Review, 85(5):1088-1105, 1995.

GRUBER, M.J. Another Puzzle: The Growth in Actively Managed Mutual Funds. The Journal of Finance, 51(3):783-810, 1996.

HUANG, J. Dynamic Liquidity Preferences of Mutual Funds. In AFA 2009 San Francisco Meetings Paper, 2015 June.

JENSEN, M.C. The Performance of Mutual Funds in the Period 1945-1964. The Journal of Finance, 23(2):389-416, 1968.

JIAO, Y.; MASSA, M.; ZHANG, H. Short Selling Meets Hedge Fund 13F: An Anatomy of Informed Demand. Journal of Financial Economics, 122(3):544567, 2016.

KHAN, M.; KOGAN, L.; SERAFEIM, G. Mutual Fund Trading Pressure: Firm Level Stock Price Impact and Timing of SEOs. The Journal of Finance, 67(4):1371-1395, 2012. 
KOSOWSKI, R.; TIMMERMANN, A.; WERMERS, R.; WHITE, H. Can Mutual Fund "Stars" Really Pick Stocks? New Evidence from a Bootstrap Analysis. The Journal of Finance, 61(6):2551-2595, 2006.

LAKONISHOK, J.; SHLEIFER, A.; VISHNY, R.W. The Impact of Institutional Trading on Stock Prices. Journal of Financial Economics, 32(1):23-43, 1992.

LAMONT, O. A. Go Down Fighting: Short Sellers vs. Firms. The Review of Asset Pricing Studies, 2(1):1-30, 2012.

MASSA, M.; PHALIPPOU, L. Mutual Funds and the Market for Liquidity. EFA 2005 Moscow Meetings Paper, May 2005.

MOTA, L. R. da. The Market for Borrowing Securities in Brazil. 2014. $36 \mathrm{f}$. Dissertação (Mestrado) Escola de Pós-Graduação em Economia, Fundação Getúlio Vargas, Rio de Janeiro, 2013.

NOFSINGER, J.R.; SIAS, R.W. Herding and Feedback Trading by Institutional and Individual Investors. The Journal of Finance, 54(6):2263-2295, 1999.

SAFFI, P. A.; SIGURDSSON, K. Price Efficiency and Short Selling. The Review of Financial Studies, 24(3):821-852, 2010.

SANTOS, A. B. Empréstimo de Ações e Juros sobre Capital Próprio: os desdobramentos da Lei no 13.043/2014. 2018. 107 f. Tese (Doutorado) Faculdade de Economia, Universidade Federal de Juiz de Fora, Juiz de Fora, 2018.

SIAS, R.W. Institutional Herding. The Review of Financial Studies, 17(1):165206, 2004.

SIAS, R.W.; STARKS, L.T.; TITMAN, S. Changes in Institutional Ownership and Stock Returns: Assessment and Methodology. The Journal of Business, 79(6):2869-2910, 2006.

SIRRI, E.R.; TUFANO, P. (1998). Costly Search and Mutual Fund Flows. The Journal of Finance, 53(5):1589-1622, 1998.

WANG, A. W. Institutional Equity Flows, Liquidity Risk and Asset Pricing. Unpublished Working Paper, University of California at Irvine, 2003.

WARTHER, V.A. Aggregate Mutual Fund Flows and Security Returns. Journal of Financial Economics, 39(2-3):209-235, 1995.

WERMERS, R. Mutual Fund Herding and the Impact on Stock Prices. The Journal of Finance, 54(2):581-622, 1999.

WERMERS, R. Mutual Fund Performance: An Empirical Decomposition into Stock-Picking Talent, Style, Transactions Costs, and Expenses. The Journal of Finance, 55(4): 1655-1695, 2000. 
YAN, X.; \& ZHANG, Z. Institutional Investors and Equity Returns: Are ShortTerm Institutions Better Informed?. The Review of Financial Studies, 22(2):893-924, 2007.

ZHENG, L. Is Money Smart? A Study of Mutual Fund Investors' Fund Selection Ability. The Journal of Finance, 54(3):901-933, 1999.

YAN, X. S. Liquidity, Investment Style, and the Relation Between Fund Size and Fund Performance. Journal of Financial and Quantitative Analysis, 43(3): 741-767, 2008. 
7.

Appendix

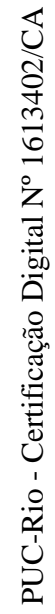




\section{Appendix 1: Adjustment Factor for Adjusted Stock Prices} Source: Economatica

The formulas below show the calculation of the adjustment factor for each type of corporate action. Stock prices prior to the corporate action (from the beginning of the series to the day before the corporate action) are multiplied by this factor so that they are comparable to the stock prices after the corporate action.

- Cash Dividends: $\quad \mathrm{F}=1-\left(\frac{\mathrm{D}}{\mathrm{Pu}}\right)$

- Stock Dividends: $\mathrm{F}=\frac{1}{(1+\mathrm{b})}$

- Stock Splits: $\quad F=\frac{1}{d}$

- Capital Reduction: $\quad F=\frac{1}{(1-r)}$

- Reversed Splits: $\quad F=g$

- Rights Issues: $\mathrm{F}=\frac{(\mathrm{Pu}+\mathrm{s} * \mathrm{~S})}{((1+\mathrm{s}) * \mathrm{Pu})}$

- Spinoff: $\quad \mathrm{F}=1-\left(\frac{\mathrm{c}}{100}\right)$

Where:

- $\mathrm{F}=$ adjustment factor

- $\mathrm{Pu}=$ original price at last date WITH right

- $\mathrm{D}=$ dividend value

- $\quad \mathrm{b}=$ number of new shares received for each share held

- $\mathrm{d}=$ number of new shares replacing each old share

- $r=$ number of shares cancelled for each share held

- $\mathrm{g}=$ number of old shares being replaced by each new share

- $\mathrm{S}=$ subscription price

- $\mathrm{s}=$ number of new shares offered for each share held

- $\quad \mathrm{c}=$ percent of the market value represented by the spunoff unit 
Table 1: Summary Statistics by Stock

Number of Market Cap (Stock Class) $\quad$ ADTV (Last 3 Months) Mean Fund Holdings as \% of Mkt Cap $\quad$ Mean Fund Holdings / ADTV

\begin{tabular}{|c|c|c|c|c|c|c|c|c|c|c|}
\hline \multirow{2}{*}{\multicolumn{2}{|c|}{$\#$ Stock }} & \multirow{2}{*}{ Months } & \multirow[b]{2}{*}{ Mean (R\$̦ millions) } & \multirow[b]{2}{*}{ Mean (R\$ millions) } & & \\
\hline & & & & & LONG & SHORT & NET & DaysLong & DaysSHORT & DaysNET \\
\hline 1 & ABEV3 & 59 & $R \$ 290.655,1$ & $R \$ 243,1$ & $1,1 \%$ & $0,3 \%$ & $0,8 \%$ & 13,98 & 3,86 & 10,15 \\
\hline 2 & ALLL3 & 36 & $\mathrm{R} \$ 6.450,3$ & $\mathrm{R} \$ 28,7$ & $8,6 \%$ & $1,0 \%$ & $7,6 \%$ & 18,07 & 2,24 & 15,89 \\
\hline 3 & AMBV4 & 90 & $\mathrm{R} \$ 58.850,4$ & $\mathrm{R} \$ 69,1$ & $2,0 \%$ & $0,5 \%$ & $1,5 \%$ & 16,78 & 4,59 & 12,14 \\
\hline 4 & ARCZ6 & 46 & $\mathrm{R} \$ 4.946,5$ & $\mathrm{R} \$ 23,0$ & $4,4 \%$ & $1,9 \%$ & $2,6 \%$ & 9,68 & 6,84 & 2,75 \\
\hline 5 & BBAS3 & 154 & $\mathrm{R} \$ 69.682,2$ & $R \$ 160,6$ & $5,8 \%$ & $0,3 \%$ & $5,5 \%$ & 28,12 & 1,64 & 26,43 \\
\hline 6 & BBDC3 & 57 & $\mathrm{R} \$ 80.115,8$ & $\mathrm{R} \$ 45,1$ & $0,9 \%$ & $0,3 \%$ & $0,6 \%$ & 15,73 & 4,51 & 11,31 \\
\hline 7 & BBDC4 & 154 & $\mathrm{R} \$ 64.664,3$ & $\mathrm{R} \$ 223,9$ & $6,2 \%$ & $0,8 \%$ & $5,4 \%$ & 18,82 & 2,50 & 16,32 \\
\hline 8 & BBSE3 & 55 & $\mathrm{R} \$ 57.962,2$ & $\mathrm{R} \$ 123,7$ & $2,5 \%$ & $0,2 \%$ & $2,4 \%$ & 12,00 & 0,87 & 11,14 \\
\hline 9 & BISA3 & 34 & $\mathrm{R} \$ 2.397,7$ & $\mathrm{R} \$ 19,4$ & $9,1 \%$ & $2,0 \%$ & $7,1 \%$ & 11,32 & 2,13 & 9,26 \\
\hline 10 & BRAP4 & 146 & $R \$ 6.335,3$ & $\mathrm{R} \$ 39,4$ & $20,9 \%$ & $0,6 \%$ & $20,3 \%$ & 30,68 & 0,89 & 29,80 \\
\hline 11 & BRFS3 & 106 & $\mathrm{R} \$ 35.311,6$ & $\mathrm{R} \$ 111,7$ & $12,2 \%$ & $0,6 \%$ & $11,6 \%$ & 42,10 & 2,11 & 40,00 \\
\hline 12 & BRKM5 & 124 & $\mathrm{R} \$ 7.084,8$ & $\mathrm{R} \$ 34,8$ & $10,2 \%$ & $1,1 \%$ & $9,2 \%$ & 20,82 & 2,06 & 18,81 \\
\hline 13 & BRML3 & 87 & $\mathrm{R} \$ 8.979,7$ & $\mathrm{R} \$ 60,4$ & $12,2 \%$ & $1,2 \%$ & $11,0 \%$ & 18,18 & 1,86 & 16,37 \\
\hline 14 & BRTO4 & 29 & $\mathrm{R} \$ 4.014,5$ & $\mathrm{R} \$ 18,2$ & $13,4 \%$ & $0,5 \%$ & $12,9 \%$ & 30,16 & 1,02 & 29,14 \\
\hline 15 & BRTP4 & 29 & $\mathrm{R} \$ 4.645,5$ & $\mathrm{R} \$ 15,9$ & $6,3 \%$ & $1,5 \%$ & $4,8 \%$ & 22,03 & 5,68 & 16,35 \\
\hline 16 & BTOW3 & 45 & $\mathrm{R} \$ 5.619,8$ & $\mathrm{R} \$ 37,6$ & $9,0 \%$ & $0,9 \%$ & $8,1 \%$ & 13,76 & 1,40 & 12,38 \\
\hline 17 & BVMF3 & 113 & $\mathrm{R} \$ 25.026,7$ & $\mathrm{R} \$ 160,0$ & $7,0 \%$ & $1,1 \%$ & $5,9 \%$ & 11,25 & 1,70 & 9,57 \\
\hline 18 & CCRO3 & 152 & $\mathrm{R} \$ 22.360,7$ & $\mathrm{R} \$ 58,2$ & $2,9 \%$ & $0,4 \%$ & $2,5 \%$ & 12,62 & 1,93 & 10,73 \\
\hline 19 & CESP6 & 48 & $\mathrm{R} \$ 5.312,4$ & $\mathrm{R} \$ 39,9$ & $16,5 \%$ & $0,3 \%$ & $16,1 \%$ & 25,54 & 0,73 & 25,00 \\
\hline 20 & CIEL3 & 101 & $\mathrm{R} \$ 50.202,4$ & $\mathrm{R} \$ 127,4$ & $2,3 \%$ & $0,2 \%$ & $2,0 \%$ & 9,54 & 0,85 & 8,72 \\
\hline 21 & CMIG4 & 154 & $\mathrm{R} \$ 9.947,6$ & $\mathrm{R} \$ 60,5$ & $11,2 \%$ & $2,1 \%$ & $9,1 \%$ & 18,39 & 4,22 & 14,11 \\
\hline 22 & CPFE3 & 52 & $\mathrm{R} \$ 18.808,0$ & $R \$ 25,4$ & $12,6 \%$ & $0,4 \%$ & $12,2 \%$ & 96,00 & 3,01 & 93,02 \\
\hline 23 & CPLE6 & 55 & $\mathrm{R} \$ 3.624,7$ & $\mathrm{R} \$ 21,0$ & $15,2 \%$ & $2,4 \%$ & $12,8 \%$ & 26,35 & 4,21 & 22,26 \\
\hline 24 & CRUZ3 & 41 & $R \$ 29.518,9$ & $R \$ 23,1$ & $1,0 \%$ & $0,4 \%$ & $0,5 \%$ & 12,97 & 6,15 & 6,80 \\
\hline 25 & CSAN3 & 143 & $\mathrm{R} \$ 11.610,0$ & $R \$ 37,6$ & $5,4 \%$ & $0,5 \%$ & $4,9 \%$ & 17,12 & 1,78 & 15,37 \\
\hline 26 & CSNA3 & 152 & $R \$ 20.932,2$ & $R \$ 76,0$ & $4,8 \%$ & $0,8 \%$ & $4,0 \%$ & 13,52 & 1,94 & 11,61 \\
\hline 27 & CTIP3 & 53 & $\mathrm{R} \$ 8.488,9$ & $R \$ 55,9$ & $20,0 \%$ & $1,7 \%$ & $18,3 \%$ & 31,39 & 2,54 & 28,86 \\
\hline 28 & CYRE3 & 112 & $\mathrm{R} \$ 6.603,4$ & $\mathrm{R} \$ 49,7$ & $8,0 \%$ & $1,9 \%$ & $6,1 \%$ & 10,66 & 2,68 & 8,07 \\
\hline 29 & ELET3 & 92 & $\mathrm{R} \$ 22.340,1$ & $\mathrm{R} \$ 35,3$ & $4,1 \%$ & $0,2 \%$ & $3,9 \%$ & 25,03 & 1,23 & 23,81 \\
\hline 30 & ELET6 & 61 & $\mathrm{R} \$ 5.750,4$ & $\mathrm{R} \$ 27,7$ & $22,2 \%$ & $3,3 \%$ & $18,8 \%$ & 40,90 & 7,22 & 33,88 \\
\hline
\end{tabular}


Table 1: Summary Statistics by Stock (continued)

Number of Market Cap (Stock Class) $\quad$ ADTV (Last 3 Months) Mean Fund Holdings as \% of Mkt Cap $\quad$ Mean Fund Holdings / ADTV

\begin{tabular}{|c|c|c|c|c|c|c|c|c|c|c|}
\hline & & \multirow[b]{2}{*}{ Months } & \multirow[b]{2}{*}{ Mean (R\$ millions) } & \multirow[b]{2}{*}{ Mean ( $\mathrm{R} \$$ millions) } & & \\
\hline$\#$ & Stock & & & & LONG & SHORT & NET & DaysLong & DaysSHORT & DaysNET \\
\hline 31 & ELPL4 & 26 & $\mathrm{R} \$ 2.703,7$ & $R \$ 26,6$ & $8,9 \%$ & $4,3 \%$ & $4,6 \%$ & 6,33 & 3,12 & 3,32 \\
\hline 32 & ELPL6 & 36 & $R \$ 3.246,5$ & $\mathrm{R} \$ 25,3$ & $15,9 \%$ & $1,2 \%$ & $14,7 \%$ & 20,39 & 1,55 & 18,90 \\
\hline 33 & EMBR3 & 117 & $\mathrm{R} \$ 13.209,4$ & $\mathrm{R} \$ 40,4$ & $3,1 \%$ & $0,6 \%$ & $2,5 \%$ & 11,16 & 2,94 & 8,30 \\
\hline 34 & EQTL3 & 38 & $\mathrm{R} \$ 11.009,3$ & $\mathrm{R} \$ 62,3$ & $29,2 \%$ & $0,7 \%$ & $28,5 \%$ & 51,64 & 1,26 & 50,42 \\
\hline 35 & ESTC3 & 59 & $\mathrm{R} \$ 6.554,6$ & $\mathrm{R} \$ 65,3$ & $7,7 \%$ & $1,2 \%$ & $6,6 \%$ & 8,06 & 1,49 & 6,61 \\
\hline 36 & FIBR3 & 106 & $\mathrm{R} \$ 17.797,8$ & $R \$ 59,2$ & $2,5 \%$ & $0,3 \%$ & $2,1 \%$ & 7,79 & 1,06 & 6,74 \\
\hline 37 & GFSA3 & 84 & $\mathrm{R} \$ 2.726,5$ & $\mathrm{R} \$ 42,7$ & $17,7 \%$ & $3,2 \%$ & $14,5 \%$ & 9,74 & 1,89 & 7,90 \\
\hline 38 & GGBR4 & 156 & $\mathrm{R} \$ 16.797,8$ & $R \$ 107,9$ & $7,1 \%$ & $1,1 \%$ & $6,0 \%$ & 12,03 & 1,91 & 10,13 \\
\hline 39 & GOAU4 & 118 & $R \$ 5.675,8$ & $\mathrm{R} \$ 44,3$ & $20,8 \%$ & $1,3 \%$ & $19,5 \%$ & 36,95 & 1,05 & 35,93 \\
\hline 40 & GOLL4 & 86 & $\mathrm{R} \$ 2.740,0$ & $R \$ 27,5$ & $8,7 \%$ & $1,8 \%$ & $6,9 \%$ & 7,85 & 2,08 & 5,83 \\
\hline 41 & HGTX3 & 46 & $R \$ 5.168,2$ & $\mathrm{R} \$ 45,8$ & $8,6 \%$ & $1,8 \%$ & $6,8 \%$ & 9,82 & 2,19 & 7,75 \\
\hline 42 & HYPE3 & 95 & $\mathrm{R} \$ 13.330,6$ & $\mathrm{R} \$ 59,3$ & $7,0 \%$ & $0,9 \%$ & $6,1 \%$ & 15,74 & 1,91 & 13,86 \\
\hline 43 & ITAU4 & 38 & $\mathrm{R} \$ 44.494,6$ & $\mathrm{R} \$ 104,1$ & $3,5 \%$ & $1,0 \%$ & $2,5 \%$ & 16,07 & 4,69 & 11,20 \\
\hline 44 & ITSA4 & 156 & $\mathrm{R} \$ 32.554,8$ & $\mathrm{R} \$ 114,6$ & $12,7 \%$ & $0,6 \%$ & $12,1 \%$ & 39,65 & 1,69 & 37,97 \\
\hline 45 & ITUB4 & 107 & $\mathrm{R} \$ 94.255,8$ & $R \$ 373,0$ & $5,3 \%$ & $1,0 \%$ & $4,3 \%$ & 13,88 & 2,66 & 11,22 \\
\hline 46 & JBSS3 & 127 & $\mathrm{R} \$ 22.331,4$ & $\mathrm{R} \$ 56,3$ & $2,3 \%$ & $0,3 \%$ & $2,1 \%$ & 11,95 & 1,40 & 10,56 \\
\hline 47 & KLBN4 & 40 & $\mathrm{R} \$ 4.562,2$ & $\mathrm{R} \$ 16,6$ & $5,3 \%$ & $1,9 \%$ & $3,4 \%$ & 14,69 & 6,15 & 8,56 \\
\hline 48 & KROT3 & 57 & $\mathrm{R} \$ 20.535,9$ & $\mathrm{R} \$ 140,3$ & $5,6 \%$ & $0,9 \%$ & $4,6 \%$ & 8,28 & 1,47 & 6,80 \\
\hline 49 & LAME4 & 153 & $\mathrm{R} \$ 9.777,4$ & $\mathrm{R} \$ 39,9$ & $7,5 \%$ & $1,7 \%$ & $5,8 \%$ & 18,30 & 4,43 & 13,89 \\
\hline 50 & LREN3 & 137 & $\mathrm{R} \$ 10.241,5$ & $\mathrm{R} \$ 60,6$ & $10,3 \%$ & $1,4 \%$ & $8,9 \%$ & 15,81 & 1,98 & 13,82 \\
\hline 51 & МMХMЗ & 54 & $\mathrm{R} \$ 3.984,1$ & $\mathrm{R} \$ 38,8$ & $8,4 \%$ & $1,3 \%$ & $7,2 \%$ & 8,53 & 1,20 & 7,39 \\
\hline 52 & MRFG3 & 28 & $\mathrm{R} \$ 3.814,1$ & $R \$ 29,8$ & $6,2 \%$ & $1,7 \%$ & $4,5 \%$ & 9,22 & 2,36 & 7,04 \\
\hline 53 & MRVE3 & 106 & $\mathrm{R} \$ 5.174,7$ & $\mathrm{R} \$ 42,5$ & $5,8 \%$ & $2,5 \%$ & $3,3 \%$ & 7,02 & 3,25 & 3,81 \\
\hline 54 & MULT3 & 37 & $R \$ 10.804,0$ & $\mathrm{R} \$ 45,6$ & $4,8 \%$ & $0,6 \%$ & $4,2 \%$ & 11,15 & 1,48 & 9,67 \\
\hline 55 & NATU3 & 140 & $\mathrm{R} \$ 14.145,7$ & $\mathrm{R} \$ 37,4$ & $2,5 \%$ & $0,8 \%$ & $1,7 \%$ & 9,65 & 3,10 & 6,60 \\
\hline 56 & NETC4 & 57 & $\mathrm{R} \$ 4.532,3$ & $\mathrm{R} \$ 35,9$ & $11,1 \%$ & $0,6 \%$ & $10,5 \%$ & 14,59 & 0,84 & 13,74 \\
\hline 57 & OGXP3 & 48 & $\mathrm{R} \$ 35.998,5$ & $\mathrm{R} \$ 252,5$ & $4,6 \%$ & $1,4 \%$ & $3,2 \%$ & 4,88 & 0,78 & 4,15 \\
\hline 58 & OIBR4 & 40 & $\mathrm{R} \$ 5.729,2$ & $\mathrm{R} \$ 47,2$ & $4,0 \%$ & $1,5 \%$ & $2,5 \%$ & 4,14 & 1,75 & 2,61 \\
\hline 59 & PCAR4 & 121 & $\mathrm{R} \$ 9.975,8$ & $\mathrm{R} \$ 52,3$ & $8,3 \%$ & $1,1 \%$ & $7,2 \%$ & 18,67 & 2,37 & 16,35 \\
\hline 60 & PDGR3 & 60 & $\mathrm{R} \$ 5.151,4$ & $\mathrm{R} \$ 79,7$ & $21,9 \%$ & $3,7 \%$ & $18,2 \%$ & 13,88 & 2,25 & 11,75 \\
\hline
\end{tabular}


Table 1: Summary Statistics by Stock (continued)

Number of Market Cap (Stock Class) ADTV (Last 3 Months) Mean Fund Holdings as \% of Mkt Cap $\quad$ Mean Fund Holdings / ADTV

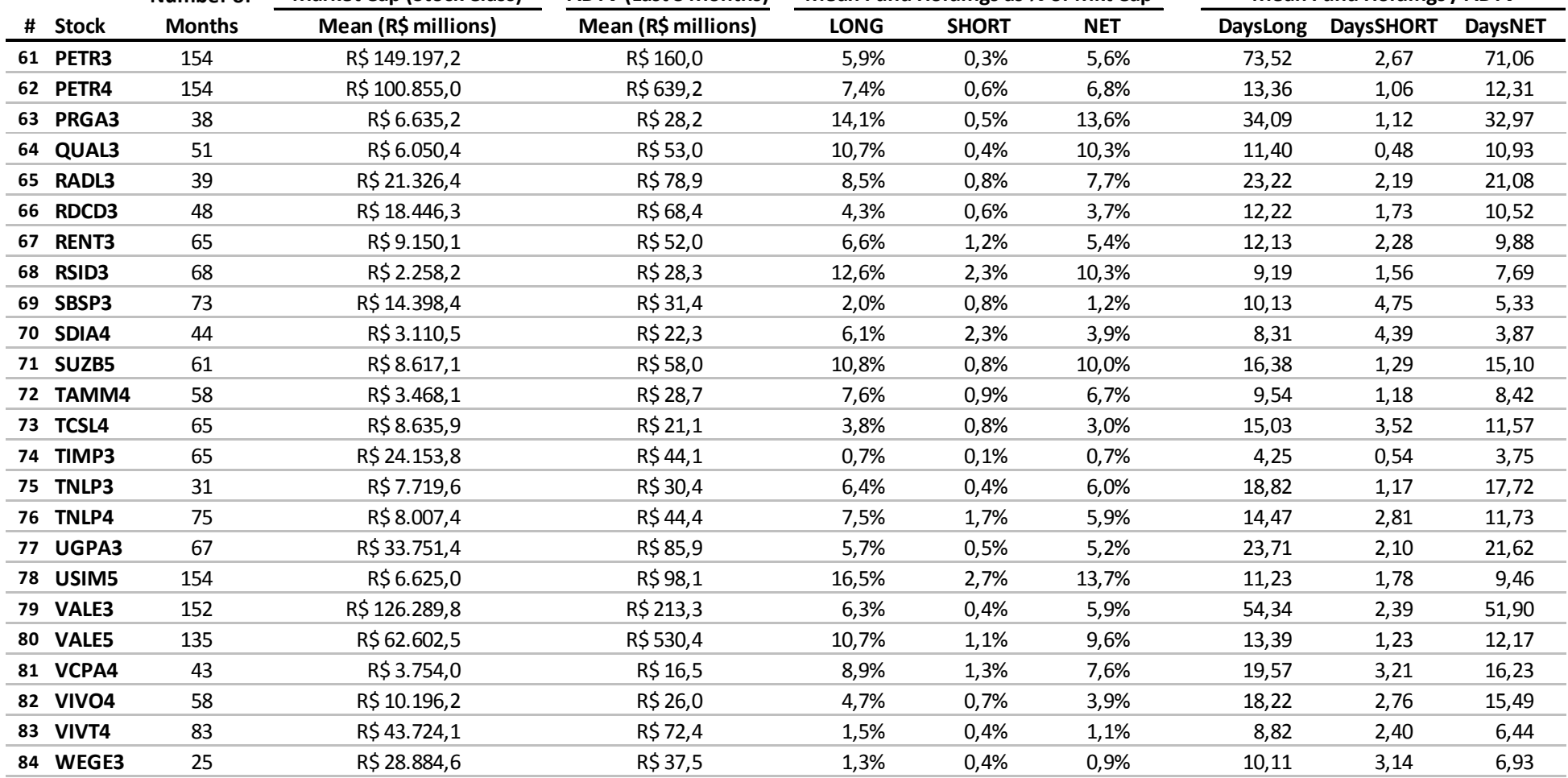


Table 2: Summary Statistics by Year

Number of Market Cap (Stock Class) $\quad$ ADTV (Last 3 Months) Mean Fund Position as \% of Mkt Cap $\quad$ Fund Position / ADTV 3 Months

\begin{tabular}{|c|c|c|c|c|c|c|c|c|c|}
\hline \multirow[b]{2}{*}{ Year } & \multirow{2}{*}{ Data Points } & \multirow{2}{*}{ Mean (R\$ millions) } & \multirow{2}{*}{ Mean (R\$ millions) } & \multicolumn{3}{|c|}{ 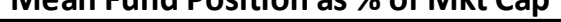 } & \\
\hline & & & & LONG & SHORT & NET & DaysLONG & DaysSHORT & DaysNET \\
\hline 2006 & 434 & $\mathrm{R} \$ 18.493$ & $\mathrm{R} \$ 38$ & $6,7 \%$ & $1,0 \%$ & $5,7 \%$ & 27,8 & 3,6 & 24,3 \\
\hline 2007 & 502 & $\mathrm{R} \$ 22.506$ & $\mathrm{R} \$ 63$ & $8,6 \%$ & $1,7 \%$ & $6,9 \%$ & 25,4 & 4,5 & 20,7 \\
\hline 2008 & 537 & $\mathrm{R} \$ 22.638$ & $\mathrm{R} \$ 82$ & $12,0 \%$ & $0,6 \%$ & $11,4 \%$ & 28,1 & 1,4 & 26,8 \\
\hline 2009 & 528 & $\mathrm{R} \$ 23.027$ & $\mathrm{R} \$ 75$ & $8,3 \%$ & $0,7 \%$ & $7,6 \%$ & 22,0 & 1,4 & 20,5 \\
\hline 2010 & 518 & $\mathrm{R} \$ 30.340$ & $\mathrm{R} \$ 98$ & $7,0 \%$ & $0,8 \%$ & $6,2 \%$ & 19,6 & 1,9 & 17,7 \\
\hline 2011 & 537 & $\mathrm{R} \$ 28.853$ & $\mathrm{R} \$ 96$ & $7,3 \%$ & $1,3 \%$ & $5,9 \%$ & 19,0 & 2,6 & 16,5 \\
\hline 2012 & 563 & $\mathrm{R} \$ 27.925$ & $\mathrm{R} \$ 98$ & $7,9 \%$ & $1,2 \%$ & $6,7 \%$ & 16,7 & 1,9 & 14,8 \\
\hline 2013 & 561 & $\mathrm{R} \$ 27.157$ & $\mathrm{R} \$ 102$ & $9,6 \%$ & $1,9 \%$ & $7,7 \%$ & 16,6 & 3,0 & 13,7 \\
\hline 2014 & 545 & $\mathrm{R} \$ 32.924$ & $\mathrm{R} \$ 108$ & $8,1 \%$ & $1,2 \%$ & $6,9 \%$ & 17,1 & 2,6 & 14,6 \\
\hline 2015 & 555 & $\mathrm{R} \$ 31.360$ & $\mathrm{R} \$ 106$ & $6,8 \%$ & $1,0 \%$ & $5,8 \%$ & 13,5 & 2,1 & 11,4 \\
\hline 2016 & 553 & $\mathrm{R} \$ 33.338$ & $\mathrm{R} \$ 113$ & $7,0 \%$ & $0,8 \%$ & $6,2 \%$ & 16,7 & 1,9 & 14,9 \\
\hline 2017 & 534 & $\mathrm{R} \$ 41.103$ & $\mathrm{R} \$ 127$ & $7,3 \%$ & $0,8 \%$ & $6,6 \%$ & 16,5 & 1,7 & 14,8 \\
\hline 2018 & 492 & $\mathrm{R} \$ 48.157$ & $\mathrm{R} \$ 181$ & $9,6 \%$ & $0,8 \%$ & $8,8 \%$ & 16,9 & 1,7 & 15,2 \\
\hline
\end{tabular}


Table 3: Regression Results: Excess Returns as Function of Fund Holdings Variables

Panel A: Aggregate Fund Holdings

\begin{tabular}{|c|c|c|c|c|c|c|c|c|}
\hline \multirow{3}{*}{$\begin{array}{c}\begin{array}{c}\text { Excess Return } \\
\text { Holding Period }\end{array} \\
(\mathrm{T}-13->\mathrm{T}-1)-12 \text { Month }\end{array}$} & \multicolumn{8}{|c|}{ Aggregate Fund Holdings as \% of Market Cap. } \\
\hline & $\mathrm{n}$ & LONC & & SHO & & $\mathrm{NE}$ & & \\
\hline & 156 & $-0,118$ & $(*)$ & $-2,089$ & $\left(\mathbf{l}^{* * *}\right)$ & $-0,055$ & & \\
\hline (T-7 ->T-1) -6 Month & 156 & $-0,070$ & ( ) & $-1,377$ & $(* * *)$ & $-0,029$ & & ) \\
\hline (T-4 -> T-1) -3 Month & 156 & 0,013 & ( ) & $-0,567$ & $(* * *)$ & 0,030 & & ) \\
\hline$(\mathrm{T}-3->\mathrm{T}-1)-2$ Month & 156 & 0,021 & ( ) & $-0,439$ & $(* * *)$ & 0,035 & & \\
\hline$(\mathrm{T}-2->\mathrm{T}-1)-1$ Month & 156 & 0,019 & $1)$ & $-0,177$ & $(*)$ & 0,025 & & \\
\hline (T-1 ->T) Current & 156 & 0,011 & ( ) & $-0,237$ & $(* *)$ & 0,018 & & \\
\hline$(\mathrm{T}->\mathrm{T}+1)+1$ Month & 156 & $-0,001$ & ( ) & $-0,191$ & $(*)$ & 0,005 & 1 & \\
\hline$(\mathrm{T}->\mathrm{T}+2)+2$ Month & 156 & $-0,007$ & ( ) & $-0,449$ & $(* * *)$ & 0,006 & & \\
\hline$(\mathrm{T}->\mathrm{T}+3)+3$ Month & 156 & $-0,002$ & ( ) & $-0,649$ & $(* * *)$ & 0,018 & & \\
\hline$(\mathrm{T}->\mathrm{T}+6)+6$ Month & 156 & 0,009 & ( ) & $-1,120$ & $(* * *)$ & 0,043 & & \\
\hline$(\mathrm{T}->\mathrm{T}+12)+12$ Month & 150 & 0,020 & i i & $-0,887$ & $(* *)$ & 0,047 & & \\
\hline$(T+4->T+5)+1$ Month & 156 & 0,006 & ( ) & $-0,212$ & $(* *)$ & 0,012 & & \\
\hline$(T+4->T+6)+2$ Month & 156 & 0,005 & ( ) & $-0,241$ & $(*)$ & 0,012 & & \\
\hline$(\mathrm{T}+4->\mathrm{T}+7)+3$ Month & 155 & 0,008 & ( ) & $-0,371$ & (**) & 0,019 & & \\
\hline$(T+4->T+10)+6$ Month & 152 & $-0,001$ & ( ) & $-0,495$ & $(*)$ & 0,014 & 1 & \\
\hline$(\mathrm{T}+4-\mathrm{T}+16)+12$ Month & 146 & $-0,032$ & ( ) & 0,125 & ( ) & $-0,037$ & 1 & 1 \\
\hline
\end{tabular}

\begin{tabular}{|c|c|c|c|c|c|c|}
\hline \multicolumn{7}{|c|}{ Aggregate Fund Holdings as Multiple of ADTV } \\
\hline$n$ & DaysL & ONG & DaysS & HORT & Daysl & \\
\hline 156 & 0,004 & $(1)$ & $-0,007$ & & 0,004 & $(1)$ \\
\hline 156 & 0,002 & ( ) & $-0,008$ & ( ) & 0,002 & ( ) \\
\hline 156 & 0,003 & $(* *)$ & 0,006 & ( ) & 0,003 & $(* *)$ \\
\hline 156 & 0,002 & $(* *)$ & 0,003 & ( ) & 0,002 & $(* *)$ \\
\hline 156 & 0,002 & $(* * *)$ & 0,005 & i i & 0,002 & $(* * *)$ \\
\hline 156 & 0,002 & $(* * *)$ & 0,007 & $(*)$ & 0,002 & $(* *)$ \\
\hline 156 & 0,000 & 1 i & $-0,004$ & ( ) & 0,000 & (i) \\
\hline 156 & 0,000 & ( ) & $-0,012$ & $(*)$ & 0,000 & ( ) \\
\hline 156 & 0,000 & i i & $-0,017$ & $(* *)$ & 0,000 & i i \\
\hline 156 & 0,000 & ( ) & $-0,045$ & $(* * *)$ & 0,001 & ( ) \\
\hline 150 & $-0,003$ & ( i & $-0,062$ & $(* * *)$ & $-0,002$ & i i \\
\hline 156 & 0,001 & ( ) & $-0,009$ & $(* *)$ & 0,001 & ( ) \\
\hline 156 & 0,000 & i i & $-0,014$ & (**) & 0,001 & 11 \\
\hline 155 & 0,000 & ( 1$)$ & $-0,022$ & $\left({ }^{* * *}\right)$ & 0,001 & ( i) \\
\hline 152 & $-0,001$ & i i & $-0,038$ & $(* * *)$ & 0,000 & i i \\
\hline 146 & $-0,006$ & (**) & $-0,029$ & $(*)$ & $-0,005$ & (*) \\
\hline
\end{tabular}

Panel B: Aggregate Fund Trades (Between T-1 and T)

\begin{tabular}{|c|c|c|c|c|c|c|c|c|}
\hline \multirow{2}{*}{$\begin{array}{l}\text { Excess Return } \\
\text { Holding Period }\end{array}$} & \multicolumn{8}{|c|}{ Aggregate Fund Trades as $\%$ of Market Cap. } \\
\hline & $\mathrm{n}$ & $\Delta \mathrm{LO}$ & & $\Delta S H$ & & $\Delta N$ & & \\
\hline$(\mathrm{T}-13->\mathrm{T}-1)-12$ Month & 155 & $-0,028$ & 1 & 0,198 & & $-0,033$ & & \\
\hline (T-7 ->T-1) -6 Month & 155 & $-0,080$ & 1 & $-0,183$ & 1 & $-0,073$ & 1 & \\
\hline (T-4 -> T-1) -3 Month & 155 & $-0,042$ & 1 & 0,112 & ( & $-0,045$ & & \\
\hline (T-3 ->T-1) -2 Month & 155 & $-0,028$ & $(1)$ & $-0,074$ & 1 & $-0,025$ & & \\
\hline (T-2 -> T-1) -1 Month & 155 & 0,015 & $(1)$ & 0,019 & 1 & 0,014 & & \\
\hline (T-1 -> T) Current & 155 & 0,019 & $(1)$ & $-0,060$ & 1 & 0,021 & & \\
\hline$(\mathrm{T}->\mathrm{T}+1)+1$ Month & 155 & 0,009 & $(1)$ & $-0,007$ & 1 & 0,009 & & \\
\hline$(\mathrm{T}->\mathrm{T}+2)+2$ Month & 155 & $-0,009$ & 1 & $-0,163$ & 1 & $-0,004$ & & \\
\hline$(\mathrm{T}->\mathrm{T}+3)+3$ Month & 155 & $-0,007$ & $(1)$ & $-0,141$ & 1 & $-0,002$ & & \\
\hline$(\mathrm{T}->\mathrm{T}+6)+6$ Month & 155 & 0,011 & $(1)$ & $-0,330$ & & 0,021 & & \\
\hline (T ->T+12) +12 Month & 149 & 0,022 & 1 & $-0,174$ & 1 & 0,027 & & 1 \\
\hline$(\mathrm{T}+4->\mathrm{T}+5)+1$ Month & 155 & 0,024 & 1 & $-0,113$ & 1 & 0,027 & & \\
\hline$(\mathrm{T}+4->\mathrm{T}+6)+2$ Month & 155 & 0,022 & 1 & $-0,023$ & 1 & 0,022 & & ) \\
\hline$(T+4->T+7)+3$ Month & 154 & 0,007 & 1 & $-0,134$ & 1 & 0,011 & & \\
\hline$(\mathrm{T}+4->\mathrm{T}+10)+6$ Month & 151 & 0,038 & & $-0,252$ & 1 & 0,045 & & \\
\hline
\end{tabular}

\begin{tabular}{|c|c|c|c|c|c|}
\hline \multicolumn{6}{|c|}{ Aggregate Fund Holdings as Multiple of ADTV } \\
\hline $\mathrm{n}$ & $\Delta$ DaysLONG & $\Delta$ DaysS & HORT & $\Delta$ DaysI & \\
\hline 155 & $-0,005()$ & 0,001 & $(1)$ & $-0,005$ & \\
\hline 155 & $-0,007 \quad(* *)$ & $-0,015$ & i i & $-0,006$ & $(* *)$ \\
\hline 155 & $-0,005 \quad(* *)$ & $-0,007$ & i i & $-0,004$ & $(* *)$ \\
\hline 155 & $-0,003 \quad(* *)$ & $-0,011$ & i i & $-0,003$ & $(*)$ \\
\hline 155 & $0,000(j)$ & $-0,004$ & ( ) & 0,000 & ( ) \\
\hline 155 & $0,005 \quad(* * *)$ & 0,017 & $(* * *)$ & 0,004 & $(* * *)$ \\
\hline 155 & $0,000(1)$ & 0,000 & (1) & 0,000 & ( ) \\
\hline 155 & $-0,001$ & $-0,004$ & (1) & $-0,001$ & ( ) \\
\hline 155 & $-0,002$ ( ) & $-0,004$ & (1) & $-0,002$ & (1) \\
\hline 155 & 0,000 ( ) & $-0,015$ & (1) & 0,001 & 1 \\
\hline 149 & $0,002 \quad(\quad)$ & $-0,018$ & ( ) & 0,003 & ( ) \\
\hline 155 & 0,001 & $-0,006$ & (1) & 0,001 & (1) \\
\hline 155 & $0,001 \quad(\quad)$ & $-0,005$ & (1) & 0,002 & (1) \\
\hline 154 & $0,001 \quad(\quad)$ & $-0,010$ & (1) & 0,002 & (1) \\
\hline 151 & $0,003(1)$ & $-0,015$ & 1 & 0,004 & 1 \\
\hline 145 & 0,005 & $-0,001$ & & 0,005 & \\
\hline
\end{tabular}

Significance: ${ }^{\star} 0.05$ probability level, ${ }^{\star \star} 0.01$ probability level, ${ }^{\star \star \star} 0.001$ probability level 
Table 4: Regression Results: Excess Returns as Function of Fund Long and Short Holdings (and Trades)

Panel A: Aggregate Fund Holdings

\begin{tabular}{|c|c|c|c|c|c|c|c|c|}
\hline \multirow{2}{*}{$\begin{array}{l}\text { Excess Return } \\
\text { Holding Period }\end{array}$} & \multicolumn{5}{|c|}{ (A1) Aggregate Fund Holdings as \% of Mkt. Cap } & \multicolumn{3}{|c|}{ (A2) Aggregate Fund Holdings as Multiple of ADTV } \\
\hline & \multirow{2}{*}{$\begin{array}{c}\text { Months } \\
156\end{array}$} & \multicolumn{2}{|c|}{ LONG } & \multicolumn{2}{|c|}{ SHORT } & \multirow{2}{*}{$\begin{array}{c}\text { Months } \\
156\end{array}$} & DaysLONG & DaysSHORT \\
\hline (T-13 -> T-1) -12 Month & & $-0,078$ & 1 & $-2,041$ & $(* * *)$ & & $0,004()$ & $-0,008(\quad)$ \\
\hline (T-7 -> T-1) -6Month & 156 & $-0,041$ & ) & $-1,349$ & $(* * *)$ & 156 & $0,002 \quad(\quad)$ & $-0,008 \quad i$ \\
\hline (T-4 -> T-1) -3 Month & 156 & 0,027 & ) & $-0,589$ & $(* * *)$ & 156 & $0,003 \quad(* *)$ & $0,005 i$ \\
\hline (T-3-> T-1) -2 Month & 156 & $0,033 \quad 1$ & ) & $-0,469$ & $(* * *)$ & 156 & 0,002 & $0,002 \quad($ \\
\hline (T-2 -> T-1) -1 Month & 156 & 0,025 & ) & $-0,205$ & $(* *)$ & 156 & $0,002 \quad(* * *)$ & 0,005 \\
\hline (T-1 -> T) Current & 156 & 0,019 & ) & $-0,259$ & $(* * *)$ & 156 & $0,002 \quad(* * *)$ & $0,007 \quad(*)$ \\
\hline$(\mathrm{T}->\mathrm{T}+1)+1$ Month & 156 & 0,005 & ) & $-0,198$ & $(* *)$ & 156 & 0,000 ( ) & $-0,004 \quad(\quad)$ \\
\hline$(\mathrm{T}->\mathrm{T}+2)+2$ Month & 156 & 0,005 & ) & $-0,454$ & $(* * *)$ & 156 & $0,000 \quad i$ & $-0,012 \quad(*)$ \\
\hline$(\mathrm{T}->\mathrm{T}+3)+3$ Month & 156 & 0,014 & ) & $-0,660$ & $(* * *)$ & 156 & $0,000 i$ & $-0,017 \quad(* *)$ \\
\hline$(T->T+6)+6$ Month & 156 & 0,031 & ) & $-1,142$ & $(* * *)$ & 156 & 0,000 & $-0,045 \quad(* * *)$ \\
\hline$(\mathrm{T}->\mathrm{T}+12)+12$ Month & 150 & 0,037 & 1 & $-0,915$ & $(* *)$ & 150 & $-0,003 \quad($ & $-0,061 \quad(* * *)$ \\
\hline$(\mathrm{T}+4->\mathrm{T}+5)+1$ Month & 156 & 0,011 & ) & $-0,223$ & $(* *)$ & 156 & 0,001 & $-0,009 \quad(* *)$ \\
\hline$(T+4->T+6)+2$ Month & 156 & 0,010 & ) & $-0,250$ & $(*)$ & 156 & 0,001 & $-0,014$ \\
\hline$(\mathrm{T}+4->\mathrm{T}+7)+3$ Month & 155 & 0,016 & ) & $-0,383$ & $(* *)$ & 155 & 0,001 & $-0,022 \quad(* * *)$ \\
\hline$(T+4->T+10)+6$ Month & 152 & 0,008 & ) & $-0,501$ & $(*)$ & 152 & $-0,001 \quad(\quad)$ & $-0,038 \quad(* * *)$ \\
\hline$(T+4->T+16)+12$ Month & 146 & $-0,035$ & ( ) & 0,143 & ( i) & 146 & $-0,006 \quad(* *)$ & $-0,027 \quad(*)$ \\
\hline
\end{tabular}

Panel B: Aggregate Fund Trades (Between T-1 and T)

\begin{tabular}{|c|c|c|c|c|c|c|c|c|}
\hline \multirow{3}{*}{$\begin{array}{c}\begin{array}{c}\text { Excess Return } \\
\text { Holding Period }\end{array} \\
(\mathrm{T}-13->\mathrm{T}-1)-12 \text { Month }\end{array}$} & \multicolumn{5}{|c|}{ (B1) Aggregate Fund Trades as $\%$ of Mkt. Cap } & \multicolumn{3}{|c|}{ (B2) Aggregate Fund Trades as Multiple of ADTV } \\
\hline & \multirow{2}{*}{$\begin{array}{c}\text { Months } \\
155\end{array}$} & \multicolumn{2}{|c|}{$\Delta$ LONG } & \multicolumn{2}{|c|}{$\Delta$ SHORT } & \multirow{2}{*}{$\begin{array}{c}\text { Months } \\
155\end{array}$} & $\Delta$ DaysLONG & $\triangle$ DaysSHORT \\
\hline & & $-0,029$ & ) & $0,204 \quad($ & ) & & $-0,005()$ & $0,002 \quad(\quad)$ \\
\hline (T-7 -> T-1) -6 Month & 155 & $-0,079$ & ( ) & $-0,166$ & ) & 155 & $-0,007 \quad(* *)$ & $-0,013$ \\
\hline (T-4 -> T-1) -3 Month & 155 & $-0,043$ & ( ) & 0,121 & ) & 155 & $-0,005 \quad(* *)$ & $-0,005$ \\
\hline (T-3 -> T-1) -2 Month & 155 & $-0,028$ & $(1)$ & $-0,068$ & ) & 155 & $-0,003 \quad(*)$ & $-0,010$ \\
\hline (T-2 -> T-1) -1 Month & 155 & 0,015 & ( ) & 0,015 & ) & 155 & $0,000 \quad(\quad)$ & $-0,004$ \\
\hline (T-1 -> T) Current & 155 & 0,020 & 11 & $-0,064$ & ) & 155 & $0,005 \quad(* * *)$ & 0,016 \\
\hline$(\mathrm{T}->\mathrm{T}+1)+1$ Month & 155 & 0,009 & 11 & $-0,009$ & ) & 155 & $0,000 \quad(\quad)$ & 0,000 \\
\hline$(\mathrm{T}->\mathrm{T}+2)+2$ Month & 155 & $-0,008$ & ( ) & $-0,161$ & ) & 155 & $-0,001$ & $-0,004$ \\
\hline$(\mathrm{T}->\mathrm{T}+3)+3$ Month & 155 & $-0,006$ & ( ) & $-0,140$ & ) & 155 & $-0,002$ & $-0,003$ \\
\hline$(\mathrm{T}->\mathrm{T}+6)+6$ Month & 155 & 0,013 & ( ) & $-0,333$ & ) & 155 & 0,000 & $-0,015$ \\
\hline$(\mathrm{T}->\mathrm{T}+12)+12$ Month & 149 & 0,023 & $1)$ & $-0,179$ & 1 & 149 & 0,002 & $-0,018$ \\
\hline$(\mathrm{T}+4->\mathrm{T}+5)+1$ Month & 155 & 0,025 & ) & $-0,118$ & ) & 155 & 0,001 & $-0,006$ \\
\hline$(\mathrm{T}+4->\mathrm{T}+6)+2$ Month & 155 & 0,022 & ) & $-0,028$ & ) & 155 & 0,001 & $-0,005$ \\
\hline$(T+4->T+7)+3$ Month & 154 & 0,007 & ) & $-0,136$ & ) & 154 & 0,002 & $-0,011$ \\
\hline$(T+4->T+10)+6$ Month & 151 & 0,039 & ) & $-0,261$ & ) & 151 & 0,004 & $-0,016$ \\
\hline$(T+4->T+16)+12$ Month & 145 & 0,057 & ( ) & 0,483 & ( ) & 145 & 0,005 & $-0,002$ \\
\hline
\end{tabular}

Significance: ${ }^{*} 0.05$ probability level, ${ }^{* \star} 0.01$ probability level, ${ }^{* \star} 0.001$ probability level 
Table 5: Backtest: Fund Holdings as \% of Market Cap.

Panel A: Aggregate Fund Long Holdings as \% of Market Cap. (LONG)

\begin{tabular}{|c|c|c|c|c|c|c|c|c|c|c|}
\hline \multirow[b]{2}{*}{ Holding Period } & \multicolumn{3}{|c|}{ LONG Mean Value by Tercile } & \multicolumn{3}{|c|}{ Mean Return: 1st Tercile (Sell) } & \multicolumn{2}{|c|}{ Mean Return: 3st Tercile (Buy) } & \multicolumn{2}{|c|}{ 3rd Tercile minus 1st Tercile } \\
\hline & 1st & $3 \mathrm{rd}$ & $\Delta$ & Period & Annualized & & Period & Annualized & Period & Annualized \\
\hline$(\mathrm{T}->\mathrm{T}+1)+1$ Month & $2.67 \%$ & $15.42 \%$ & $-12.75 \%$ & $0.088 \%$ & $1.062 \%$ & 1 & $0.175 \%$ & $2.116 \%$ & $0.087 \%$ & $1.044 \%$ \\
\hline ( $\mathrm{T}->\mathrm{T}+2)+2$ Month & $2.67 \%$ & $15.42 \%$ & $-12.75 \%$ & $0.309 \%$ & $1.869 \%$ & j & $0.284 \%$ & $1.718 \%$ & $-0.025 \%$ & $-0.148 \%$ \\
\hline$(\mathrm{T}->\mathrm{T}+3)+3$ Month & $2.67 \%$ & $15.42 \%$ & $-12.74 \%$ & $0.223 \%$ & $0.893 \%$ & 1 & $0.324 \%$ & $1.303 \%$ & $0.102 \%$ & $0.407 \%$ \\
\hline$(\mathrm{T}->\mathrm{T}+6)+6$ Month & $2.67 \%$ & $15.43 \%$ & $-12.76 \%$ & $-0.004 \%$ & $-0.008 \%$ & ) & $0.555 \%$ & $1.113 \%$ & $0.559 \%$ & $1.121 \%$ \\
\hline (T -> T+12) +12 Month & $2.68 \%$ & $15.24 \%$ & $-12.56 \%$ & $0.430 \%$ & $0.430 \%$ & 1 & $1.070 \%$ & $1.070 \%$ & $0.640 \%$ & $0.640 \%$ \\
\hline$(\mathrm{T}+4->\mathrm{T}+5)+1$ Month & $2.67 \%$ & $15.43 \%$ & $-12.75 \%$ & $-0.155 \%$ & $-1.842 \%$ & ) & $0.026 \%$ & $0.311 \%$ & $0.181 \%$ & $2.190 \%$ \\
\hline$(\mathrm{T}+4->\mathrm{T}+6)+2$ Month & $2.67 \%$ & $15.43 \%$ & $-12.76 \%$ & $-0.193 \%$ & $-1.151 \%$ & ) & $-0.010 \%$ & $-0.060 \%$ & $0.183 \%$ & $1.101 \%$ \\
\hline$(T+4->T+7)+3$ Month & $2.67 \%$ & $15.40 \%$ & $-12.73 \%$ & $-0.141 \%$ & $-0.562 \%$ & 1 & $-0.069 \%$ & $-0.277 \%$ & $0.072 \%$ & $0.287 \%$ \\
\hline$(T+4->T+10)+6$ Month & $2.68 \%$ & $15.30 \%$ & $-12.63 \%$ & $0.229 \%$ & $0.459 \%$ & ) & $-0.120 \%$ & $-0.240 \%$ & $-0.350 \%$ & $-0.698 \%$ \\
\hline$(T+4->T+16)+12$ Month & $2.67 \%$ & $15.15 \%$ & $-12.49 \%$ & $0.167 \%$ & $0.167 \%$ & 1 & $0.291 \%$ & $0.291 \%$ & $0.123 \%$ & $0.123 \%$ \\
\hline
\end{tabular}

Panel B: Aggregate Fund Short Holdings as \% of Market Cap. (SHORT)

\begin{tabular}{|c|c|c|c|c|c|c|c|c|c|}
\hline \multirow[b]{2}{*}{ Holding Period } & \multicolumn{3}{|c|}{ SHORT Mean Value by Tercile } & \multicolumn{2}{|c|}{ Mean Return: 1st Tercile (Buy) } & \multicolumn{2}{|c|}{ Mean Return: 3st Tercile (Sell) } & \multicolumn{2}{|c|}{ 1st Tercile minus 3rd Tercile } \\
\hline & 1st & 3rd & $\Delta$ & Period & Annualized & Period & Annualized & Period & Annualized \\
\hline$(\mathrm{T}->\mathrm{T}+1)+1$ Month & $0.25 \%$ & $2.24 \%$ & $-1.99 \%$ & $0.358 \%$ & $4.386 \% \quad 1$ & $-0.198 \%$ & $-2.350 \% \quad 1$ & $0.556 \%$ & $6.884 \% \quad 1$ \\
\hline$(\mathrm{T}->\mathrm{T}+2)+2$ Month & $0.25 \%$ & $2.24 \%$ & $-2.00 \%$ & $0.550 \%$ & $3.347 \% \quad 1$ & $-0.148 \%$ & $-0.884 \%$ & $0.698 \%$ & $4.263 \%$ \\
\hline ( $\mathrm{T}->\mathrm{T}+3)+3$ Month & $0.25 \%$ & $2.25 \%$ & $-2.00 \%$ & $0.898 \%$ & $3.640 \%(* *)$ & $-0.374 \%$ & $-1.486 \%$ & $1.271 \%$ & $5.183 \%$ \\
\hline$(\mathrm{T}->\mathrm{T}+6)+6$ Month & $0.25 \%$ & $2.25 \%$ & $-2.00 \%$ & $337 \%$ & $2.691 \% \quad(* *)$ & $-0.918 \%$ & $-1.828 \%$ & $255 \%$ & $4.561 \%$ \\
\hline$(\mathrm{T}->\mathrm{T}+12)+12$ Month & $0.25 \%$ & $28 \%$ & $-2.02 \%$ & $392 \%$ & $2.392 \% \quad(* * *)$ & $-1.793 \%$ & $-1.793 \%$ & $185 \%$ & $4.185 \%$ \\
\hline$(T+4->T+5)+1 \Lambda$ & $0.25 \%$ & $2.25 \%$ & $-2.00 \%$ & $0.058 \%$ & $0.700 \%$ & $-0.267 \%$ & $60 \%$ & $0.325 \%$ & $3.975 \%$ \\
\hline$(T+4->T+6)+2 \Lambda$ & $0.25 \%$ & $2.25 \%$ & $-2.00 \%$ & $0.201 \%$ & $1.209 \%$ & $-0.380 \%$ & $-2.257 \%$ & $0.580 \%$ & $3.533 \%$ \\
\hline$(T+4->T+7)+3 N$ & $0.25 \%$ & $2.25 \%$ & $-2.00 \%$ & $0.572 \%$ & $2.306 \%$ & $-0.736 \%$ & $-2.913 \%$ & $1.308 \%$ & $5.336 \%$ \\
\hline$(\mathrm{T}+4->\mathrm{T}+10)+6$ Month & $0.25 \%$ & $2.27 \%$ & $-2.02 \%$ & $1.311 \%$ & $2.639 \%$ & $-0.971 \%$ & $-1.933 \%$ & $2.282 \%$ & $4.617 \%$ \\
\hline$(T+4->T+16)+12$ Month & $0.25 \%$ & $2.30 \%$ & $-2.05 \%$ & $2.476 \%$ & $2.476 \%$ (***) & $-2.377 \%$ & $-2.377 \%$ & $4.853 \%$ & $4.853 \%$ \\
\hline
\end{tabular}

Panel C: Aggregate Fund Net Holdings as \% of Market Cap. (NET)

Mean Return: 1st Tercile (Sell) Mean Return: 3st Tercile (Buy) 3rd Tercile minus 1st Tercile

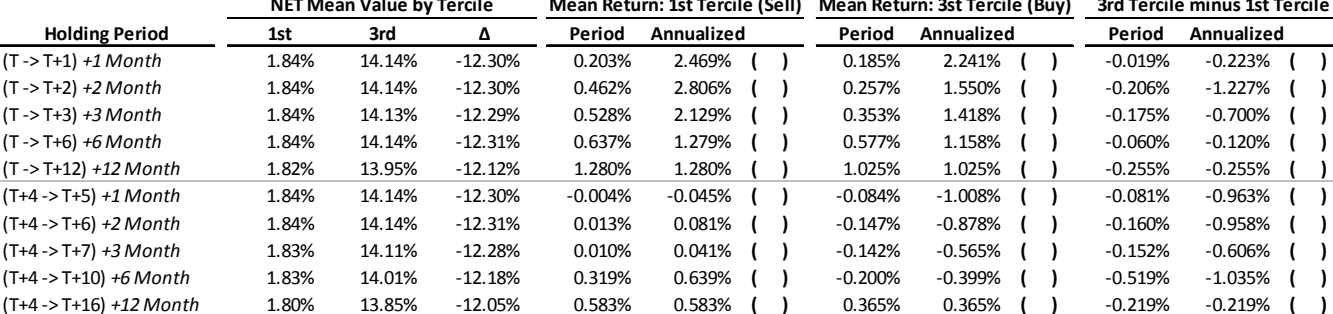

Significance:

* 0.05 probability level

** 0.01 probability level

$\star \star \star 0.001$ probability level 
Table 6: Backtest: Fund Trades as \% of Market Cap.

Panel A: Aggregate Fund Long Trades as \% of Market Cap. ( $\Delta$ LONG)

\begin{tabular}{|c|c|c|c|c|c|c|c|c|c|}
\hline \multirow[b]{2}{*}{ Holding Period } & \multicolumn{3}{|c|}{$\Delta$ LONG Mean Value by Tercile } & \multicolumn{2}{|c|}{ Mean Return: 1st Tercile (Sell) } & \multicolumn{2}{|c|}{ Mean Return: 3st Tercile (Buy) } & \multicolumn{2}{|c|}{ 3rd Tercile minus 1st Tercile } \\
\hline & 1st & 3 rd & $\Delta$ & Period & Annualized & Period & Annualized & Period & Annualized \\
\hline$(\mathrm{T}->\mathrm{T}+1)+1$ Month & $-1.26 \%$ & $1.39 \%$ & $-2.65 \%$ & $-0.430 \%$ & $-5.038 \% \quad($ & $0.592 \%$ & $7.345 \% \quad(*)$ & $1.022 \%$ & $12.981 \% \quad(* * *)$ \\
\hline$(\mathrm{T}->\mathrm{T}+2)+2$ Month & $-1.26 \%$ & $1.39 \%$ & $-2.65 \%$ & $-0.260 \%$ & $-1.548 \% \quad($ & $0.663 \%$ & $4.047 \%(1)$ & $0.923 \%$ & $5.667 \%$ \\
\hline$(\mathrm{T}->\mathrm{T}+3)+3$ Month & $-1.26 \%$ & $1.39 \%$ & $-2.65 \%$ & $-0.407 \%$ & $-1.620 \%$ & $0.831 \%$ & $3.366 \%$ & $1.238 \%$ & $5.047 \%$ \\
\hline$(\mathrm{T}->\mathrm{T}+6)+6$ Month & $-1.26 \%$ & $1.39 \%$ & $-2.65 \%$ & -0.29 & $-0.585 \% \quad($ & $1.723 \%$ & $3.476 \%(*)$ & $2.016 \%$ & $4.073 \%$ \\
\hline$(\mathrm{T}->\mathrm{T}+12)+12$ Month & $-1.27 \%$ & $1.41 \%$ & $-2.68 \%$ & $0.050 \%$ & $0.050 \% \quad 1$ & $2.371 \%$ & $2.371 \%$ & $2.321 \%$ & $2.321 \%$ \\
\hline$(\mathrm{T}+4->\mathrm{T}+5)+1$ Month & $-1.26 \%$ & $1.39 \%$ & $-2.65 \%$ & $-0.188 \%$ & $-2.233 \% \quad($ & $0.343 \%$ & $4.195 \%$ & $0.531 \%$ & $6.562 \%$ \\
\hline$(\mathrm{T}+4->\mathrm{T}+6)+2$ Month & $-1.26 \%$ & $1.39 \%$ & $-2.65 \%$ & $-0.002 \%$ & $-0.011 \% \quad($ & $0.548 \%$ & $3.331 \%$ & $0.550 \%$ & $3.343 \%$ \\
\hline$(T+4->T+7)+3$ Month & $-1.26 \%$ & $1.39 \%$ & $-2.66 \%$ & $0.088 \%$ & $0.352 \% \quad 1$ & $0.599 \%$ & $2.417 \%$ & $0.511 \%$ & $2.060 \%$ \\
\hline$(\mathrm{T}+4->\mathrm{T}+10)+6$ Month & $-1.27 \%$ & $1.40 \%$ & $-2.67 \%$ & $0.218 \%$ & $0.436 \% \quad($ & $0.970 \%$ & $1.950 \%$ & $0.753 \%$ & $1.511 \%$ \\
\hline$(\mathrm{T}+4->\mathrm{T}+16)+12$ Month & $-1.31 \%$ & $1.40 \%$ & $-2.71 \%$ & $-0.173 \%$ & $-0.173 \% \quad(\quad)$ & $0.936 \%$ & $0.936 \%$ & $1.109 \%$ & $1.109 \%$ \\
\hline
\end{tabular}

Panel B: Aggregate Fund Short Trades as \% of Market Cap. ( $\triangle$ SHORT)

\begin{tabular}{|c|c|c|c|c|c|c|c|c|c|}
\hline \multirow[b]{2}{*}{ Holding Period } & \multicolumn{3}{|c|}{$\Delta$ SHORT Mean Value by Tercile } & \multicolumn{2}{|c|}{ Mean Return: 1st Tercile (Buy) } & \multicolumn{2}{|c|}{ Mean Return: 3st Tercile (Sell) } & \multicolumn{2}{|c|}{ 1st Tercile minus 3rd Tercile } \\
\hline & 1st & $3 \mathrm{rd}$ & $\Delta$ & Period & Annualized & Period & Annualized & Period & Annualized \\
\hline$(\mathrm{T}->\mathrm{T}+1)+1$ Month & $-0.35 \%$ & $0.45 \%$ & $-0.80 \%$ & $0.195 \%$ & $2.365 \% \quad 1$ & $-0.116 \%$ & $-1.385 \% \quad(\quad)$ & $0.311 \%$ & $3.798 \% \quad 1$ \\
\hline$(\mathrm{T}->\mathrm{T}+2)+2$ Month & $-0.35 \%$ & $0.45 \%$ & $80 \%$ & $0.575 \%$ & $01 \%$ & $-0.130 \%$ & $775 \% \quad 1$ & $.705 \%$ & $4.303 \%$ \\
\hline$(\mathrm{T}->\mathrm{T}+3)+3$ Month & $-0.35 \%$ & $45 \%$ & $80 \%+2>2 \div$ & $322 \%$ & $293 \%$ & $-0.047 \%$ & $-0.188 \%$ & $.369 \%$ & $1.483 \%$ \\
\hline$(\mathrm{T}->\mathrm{T}+6)+6$ Month & $-0.35 \%$ & $0.45 \%$ & $-0.80 \%$ & $0.595 \%$ & $1.193 \%$ & $-0.113 \%$ & $-0.226 \%$ & $0.708 \%$ & $1.420 \%$ \\
\hline$(\mathrm{T}->\mathrm{T}+12)+12$ Month & $-0.36 \%$ & $46 \%$ & $-0.81 \%$ & $1.085 \%$ & $1.085 \%$ & $-0.008 \%$ & $-0.008 \%$ & $1.094 \%$ & $1.094 \%$ \\
\hline$(\mathrm{T}+4->\mathrm{T}+5)+1$ Month & $-0.35 \%$ & $0.45 \%$ & $-0.80 \%$ & $-0.049 \%$ & $-0.581 \%$ & $0.006 \%$ & $0.072 \%$ & $-0.055 \%$ & $-0.652 \%$ \\
\hline$(\mathrm{T}+4->\mathrm{T}+6)+2$ Month & $-0.35 \%$ & $0.45 \%$ & $-0.80 \%$ & $0.053 \%$ & $0.319 \%$ & $-0.119 \%$ & $-0.709 \% \quad 1$ & $0.172 \%$ & $1.034 \%$ \\
\hline$(\mathrm{T}+4->\mathrm{T}+7)+3$ Month & $-0.35 \%$ & $0.45 \%$ & $-0.80 \%$ & $0.063 \%$ & $0.251 \%$ & $-0.378 \%$ & $-1.502 \% \quad($ & $0.440 \%$ & $1.774 \%$ \\
\hline$(T+4->T+10)+6$ Month & $-0.36 \%$ & $0.45 \%$ & $-0.81 \%$ & $0.584 \%$ & $1.172 \%$ & $-0.694 \%$ & $-1.384 \%$ & $1.279 \%$ & $2.573 \%$ \\
\hline$\pi$ & 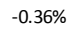 & $0.46 \%$ & $-0.82 \%$ & $0.758 \%$ & $0.758 \% \quad($ & $-1.025 \%$ & $-1.025 \% \quad($ & 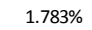 & - 78000 \\
\hline
\end{tabular}

Panel C: Aggregate Fund Net Trades as \% of Market Cap. (DNET)

\begin{tabular}{|c|c|c|c|c|c|c|c|c|c|}
\hline \multirow[b]{2}{*}{ Holding Period } & \multicolumn{3}{|c|}{$\triangle$ NET Mean Value by Tercile } & \multicolumn{2}{|c|}{ Mean Return: 1st Tercile (Sell) } & \multicolumn{2}{|c|}{ Mean Return: 3st Tercile (Buy) } & \multicolumn{2}{|c|}{ 3rd Tercile minus 1st Tercile } \\
\hline & 1st & $3 \mathrm{rd}$ & $\Delta$ & Period & Annualized & Period & Annualized & Period & Annualized \\
\hline$(\mathrm{T}->\mathrm{T}+1)+1$ Month & $-1.34 \%$ & $1.40 \%$ & $-2.74 \%$ & $-0.500 \%$ & $-5.837 \% \quad($ & $0.226 \%$ & $2.742 \% \quad 1$ & $0.726 \%$ & $9.064 \% \quad(*)$ \\
\hline$(\mathrm{T}->\mathrm{T}+2)+2$ Month & $-1.34 \%$ & $1.40 \%$ & $-2.74 \%$ & $-0.467 \%$ & $-2.769 \% \quad($ & $0.330 \%$ & $1.994 \% \quad 1$ & $0.797 \%$ & $4.875 \%$ \\
\hline$(\mathrm{T}->\mathrm{T}+3)+3$ Month & $-1.34 \%$ & $1.40 \%$ & $-2.74 \%$ & $-0.343 \%$ & $-1.364 \% \quad($ & $0.384 \%$ & $1.543 \%$ & $0.726 \%$ & $2.937 \%$ \\
\hline$(\mathrm{T}->\mathrm{T}+6)+6$ Month & $-1.34 \%$ & $1.40 \%$ & $-2.74 \%$ & $-0.453 \%$ & $-0.904 \% \quad($ & $1.366 \%$ & $2.750 \%(*)$ & $1.819 \%$ & $3.670 \%$ \\
\hline$(\mathrm{T}->\mathrm{T}+12)+12$ Month & $-1.36 \%$ & $1.41 \%$ & $-2.77 \%$ & $-0.365 \%$ & $-0.365 \% \quad($ & $1.959 \%$ & $1.959 \%$ & $2.324 \%$ & $2.324 \%$ \\
\hline$(\mathrm{T}+4->\mathrm{T}+5)+1$ Month & $-1.34 \%$ & $1.40 \%$ & $-2.74 \%$ & $-0.320 \%$ & $-3.768 \% \quad 1$ & $0.396 \%$ & $4.853 \%$ & $0.715 \%$ & $8.929 \%$ \\
\hline$(\mathrm{T}+4->\mathrm{T}+6)+2$ Month & $-1.34 \%$ & $1.40 \%$ & $-2.74 \%$ & $-0.264 \%$ & $-1.571 \% \quad($ & $0.544 \%$ & $3.311 \%$ & $0.808 \%$ & $4.947 \%$ \\
\hline$(\mathrm{T}+4->\mathrm{T}+7)+3$ Month & $-1.35 \%$ & $1.40 \%$ & $-2.75 \%$ & $-0.231 \%$ & $-0.921 \% \quad 1$ & $0.644 \%$ & $2.600 \%$ & $0.875 \%$ & $3.545 \%$ \\
\hline$(\mathrm{T}+4->\mathrm{T}+10)+6$ Month & $-1.35 \%$ & $1.40 \%$ & $-2.75 \%$ & $-0.436 \%$ & $-0.871 \% \quad($ & $1.221 \%$ & $2.457 \%$ & $1.657 \%$ & $3.342 \%$ \\
\hline$(\mathrm{T}+4->\mathrm{T}+16)+12$ Month & $-1.39 \%$ & $1.40 \%$ & $-2.80 \%$ & $-0.653 \%$ & $-0.653 \% \quad(\quad)$ & $1.297 \%$ & $1.297 \%$ & $1.951 \%$ & $1.951 \% \quad($ \\
\hline
\end{tabular}

Significance:

* 0.05 probability level

** 0.01 probability level

$\star \star \star 0.001$ probability level 
Table 7: Backtest: Fund Holdings as Multiple of ADTV

Panel A: Aggregate Fund Long Holdings as Multiple of ADTV (DaysLONG)

\begin{tabular}{|c|c|c|c|c|c|c|c|c|c|c|}
\hline \multirow[b]{2}{*}{ Holding Period } & \multicolumn{3}{|c|}{ DaysLONG Mean Value by Tercile } & \multicolumn{3}{|c|}{ Mean Return: 1st Tercile (Sell) } & \multicolumn{2}{|c|}{ Mean Return: 3st Tercile (Buy) } & \multicolumn{2}{|c|}{ 3rd Tercile minus 1st Tercile } \\
\hline & 1st & 3 rd & $\Delta$ & Period & Annualized & & Period & Annualized & Period & Annualized \\
\hline$(\mathrm{T}->\mathrm{T}+1)+1$ Month & 7.30 & 37.88 & -30.59 & $0.165 \%$ & $1.998 \%$ & 1 & $0.299 \%$ & $3.647 \% \quad 1$ & $0.134 \%$ & $1.619 \% \quad 1$ \\
\hline$(\mathrm{T}->\mathrm{T}+2)+2$ Month & 7.30 & 37.89 & -30.60 & $0.346 \%$ & $2.097 \%$ & 1 & $0.447 \%$ & $2.711 \% \quad($ & $0.100 \%$ & $0.604 \%$ \\
\hline$(\mathrm{T}->\mathrm{T}+3)+3$ Month & 7.30 & 37.90 & -30.60 & $0.247 \%$ & $0.990 \%$ & 1 & $0.746 \%$ & $3.019 \%(*)$ & $0.500 \%$ & $2.014 \%$ \\
\hline$(\mathrm{T}->\mathrm{T}+6)+6$ Month & 7.31 & 37.95 & -30.64 & $0.079 \%$ & $0.158 \%$ & 1 & $1.432 \%$ & $2.884 \% \quad(* * *)$ & $1.353 \%$ & $2.724 \%$ \\
\hline$(\mathrm{T}->\mathrm{T}+12)+12$ Month & 7.31 & 38.46 & -31.15 & $-0.913 \%$ & $-0.913 \%$ & 1 & $2.417 \%$ & $2.417 \% \quad(* * *)$ & $3.330 \%$ & $3.330 \%$ \\
\hline$(\mathrm{T}+4->\mathrm{T}+5)+1$ Month & 7.31 & 37.95 & -30.64 & $-0.215 \%$ & $-2.551 \%$ & ) & $0.146 \%$ & $1.762 \%(j)$ & $0.361 \%$ & $4.416 \%$ \\
\hline$(T+4->T+6)+2$ Month & 7.31 & 37.95 & -30.64 & $-0.131 \%$ & $-0.785 \%$ & 1 & $0.332 \%$ & $2.006 \%$ & $0.463 \%$ & $2.810 \%$ \\
\hline$(\mathrm{T}+4->\mathrm{T}+7)+3$ Month & 7.31 & 38.06 & -30.75 & $-0.125 \%$ & $-0.500 \%$ & 1 & $0.505 \%$ & $2.034 \%$ & $0.630 \%$ & $2.544 \%$ \\
\hline$(\mathrm{T}+4->\mathrm{T}+10)+6$ Month & 7.31 & 38.29 & -30.97 & $-0.404 \%$ & $-0.805 \%$ & 1 & $1.092 \%$ & $2.195 \% \quad(*)$ & $1.495 \%$ & $3.013 \%$ \\
\hline$(\mathrm{T}+4->\mathrm{T}+16)+12$ Month & 7.30 & 38.91 & -31.61 & $-0.804 \%$ & $-0.804 \%$ & ( ) & $1.759 \%$ & $1.759 \% \quad(* *)$ & $2.563 \%$ & $2.563 \%$ \\
\hline
\end{tabular}

Panel B: Aggregate Fund Short Holdings as Multiple of ADTV (DaysSHORT)

\begin{tabular}{|c|c|c|c|c|c|c|c|c|c|}
\hline \multirow[b]{2}{*}{ Holding Period } & \multicolumn{3}{|c|}{ DaysSHORT Mean Value by Tercile } & \multicolumn{2}{|c|}{ Mean Return: 1st Tercile (Buy) } & \multicolumn{2}{|c|}{ Mean Return: 3st Tercile (Sell) } & \multicolumn{2}{|c|}{ 1st Tercile minus 3rd Tercile } \\
\hline & 1st & 3rd & $\Delta$ & Period & Annualized & Period & Annualized & Period & Annualized \\
\hline$(\mathrm{T}->\mathrm{T}+1)+1$ Month & 0.69 & 4.51 & -3.82 & $0.406 \%$ & $4.982 \%(1)$ & $-0.136 \%$ & $-1.615 \% \quad($ & $0.542 \%$ & $6.696 \% \quad 1$ \\
\hline$(\mathrm{T}->\mathrm{T}+2)+2$ Month & 0.70 & 4.51 & -3.82 & $0.834 \%$ & $5.109 \%(*)$ & $-0.010 \%$ & $-0.059 \%$ & $0.844 \%$ & $5.171 \%$ \\
\hline$(\mathrm{T}->\mathrm{T}+3)+3$ Month & 0.70 & 4.51 & -3.82 & $0.994 \%$ & $4.036 \%(*)$ & $0.064 \%$ & $0.256 \%$ & $0.930 \%$ & $3.772 \%$ \\
\hline$(\mathrm{T}->\mathrm{T}+6)+6$ Month & 0.70 & 4.52 & -3.82 & $1.251 \%$ & $2.518 \%(1)$ & $0.011 \%$ & $0.022 \%$ & $1.241 \%$ & $2.496 \%$ \\
\hline$(\mathrm{T}->\mathrm{T}+12)+12$ Month & 0.71 & 4.57 & -3.86 & $1.997 \%$ & $1.997 \%(*)$ & $0.065 \%$ & $0.065 \% \quad($ & $1.932 \%$ & $1.932 \%$ \\
\hline$(\mathrm{T}+4->\mathrm{T}+5)+1$ Month & 0.70 & 4.52 & -3.82 & $-0.234 \%$ & $-2.775 \%(\quad)$ & $-0.007 \%$ & $-0.082 \%$ & $-0.227 \%$ & $-2.695 \%$ \\
\hline$(\mathrm{T}+4->\mathrm{T}+6)+2$ Month & 0.70 & 4.52 & -3.82 & $-0.083 \%$ & $-0.499 \%$ & $0.173 \%$ & $1.044 \%$ & $-0.257 \%$ & $-1.530 \%$ \\
\hline$(\mathrm{T}+4->\mathrm{T}+7)+3$ Month & 0.70 & 4.53 & -3.83 & $0.071 \%$ & $0.283 \%$ & $0.303 \%$ & $1.219 \%$ & $-0.233 \%$ & $-0.927 \%$ \\
\hline$(\mathrm{T}+4->\mathrm{T}+10)+6$ Month & 0.71 & 4.56 & -3.85 & $0.286 \%$ & $0.572 \%$ & $0.444 \%$ & $0.890 \%$ & $-0.158 \%$ & $-0.317 \%$ \\
\hline$(\mathrm{T}+4->\mathrm{T}+16)+12$ Month & 0.72 & 4.62 & -3.90 & $1.428 \%$ & $1.428 \%$ & $-0.274 \%$ & $-0.274 \%$ & $1.702 \%$ & $1.702 \%$ \\
\hline
\end{tabular}

Panel C: Aggregate Fund Net Holdings as Multiple of ADTV (DaysNET)

DaysNET Mean Value by Tercile Mean Return: 1st Tercile (Sell) Mean Return: 3st Tercile (Buy) 3rd Tercile minus 1st Tercile

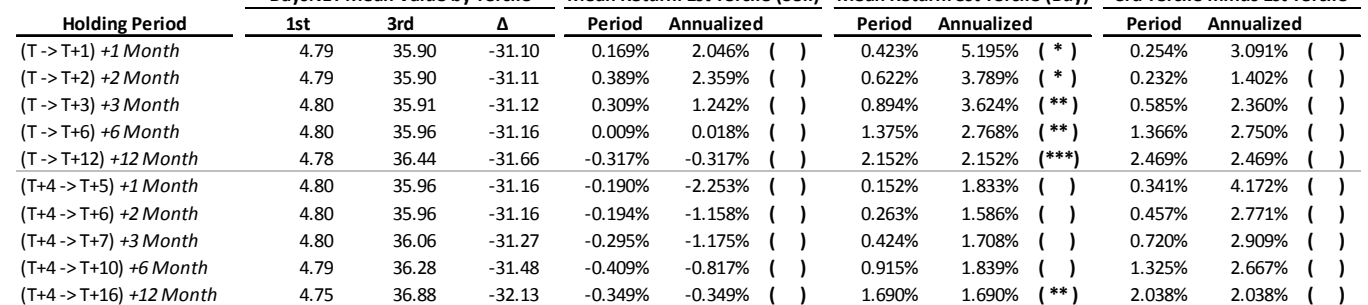

Significance:

* 0.05 probability level

** 0.01 probability level

*** 0.001 probability level 
Table 8: Backtest: Fund Trades as Multiple of ADTV

Panel A: Aggregate Fund Long Trades as Multiple of ADTV ( $\triangle$ DaysLONG)

\begin{tabular}{|c|c|c|c|c|c|c|c|c|c|c|}
\hline \multirow[b]{2}{*}{ Holding Period } & \multicolumn{3}{|c|}{$\Delta$ DaysLONG Mean Value by Tercile } & \multicolumn{3}{|c|}{ Mean Return: 1st Tercile (Sell) } & \multicolumn{2}{|c|}{ Mean Return: 3st Tercile (Buy) } & \multicolumn{2}{|c|}{ 3rd Tercile minus 1st Tercile } \\
\hline & 1st & 3rd & $\Delta$ & Period & Annualized & & Period & Annualized & Period & Annualized \\
\hline$(\mathrm{T}->\mathrm{T}+1)+1$ Month & -4.44 & 4.35 & -8.79 & $0.068 \%$ & $0.818 \%$ & ) & $-0.012 \%$ & $-0.147 \% \quad($ & $-0.080 \%$ & $-0.958 \% \quad($ \\
\hline$(\mathrm{T}->\mathrm{T}+2)+2$ Month & -4.44 & 4.35 & -8.79 & $0.418 \%$ & $2.536 \%$ & ) & $0.030 \%$ & $0.181 \%$ & $-0.388 \%$ & $-2.306 \%$ \\
\hline$(\mathrm{T}->\mathrm{T}+3)+3$ Month & -4.45 & 4.35 & -8.80 & $0.590 \%$ & $2.382 \%$ & 1 & $0.206 \%$ & $0.826 \%$ & $-0.384 \%$ & $-1.529 \%$ \\
\hline$(\mathrm{T}->\mathrm{T}+6)+6$ Month & -4.45 & 4.37 & -8.82 & $0.506 \%$ & $1.015 \%$ & ) & $0.872 \%$ & $1.752 \%$ & $0.366 \%$ & $0.733 \%$ \\
\hline$(\mathrm{T}->\mathrm{T}+12)+12$ Month & -4.54 & 4.43 & -8.97 & $0.293 \%$ & $0.293 \%$ & 1 & $1.547 \%$ & $1.547 \%$ & $1.253 \%$ & $1.253 \%$ \\
\hline$(\mathrm{T}+4->\mathrm{T}+5)+1$ Month & -4.45 & 4.37 & -8.82 & $-0.198 \%$ & $-2.349 \%$ & ) & $0.459 \%$ & $5.646 \% \quad($ & $0.657 \%$ & $8.171 \%$ \\
\hline$(\mathrm{T}+4->\mathrm{T}+6)+2$ Month & -4.45 & 4.37 & -8.82 & $-0.354 \%$ & $-2.104 \%$ & ) & $0.629 \%$ & $3.837 \%$ & $0.983 \%$ & $6.047 \%$ \\
\hline$(\mathrm{T}+4->\mathrm{T}+7)+3$ Month & -4.47 & 4.39 & -8.86 & $-0.244 \%$ & $-0.971 \%$ & 1 & $0.604 \%$ & $2.437 \% \quad($ & $0.847 \%$ & $3.433 \%$ \\
\hline$(\mathrm{T}+4->\mathrm{T}+10)+6$ Month & -4.49 & 4.43 & -8.93 & $-0.005 \%$ & $-0.010 \%$ & 1 & $1.040 \%$ & $2.091 \%$ & $1.045 \%$ & $2.101 \%$ \\
\hline$(\mathrm{T}+4->\mathrm{T}+16)+12$ Month & -4.61 & 4.51 & -9.12 & $-0.971 \%$ & $-0.971 \%$ & ( ) & $1.551 \%$ & $1.551 \%(\quad)$ & $2.522 \%$ & $2.522 \%$ \\
\hline
\end{tabular}

Panel B: Aggregate Fund Short Trades as Multiple of ADTV ( $\triangle$ DaysSHORT)

\begin{tabular}{|c|c|c|c|c|c|c|c|c|c|}
\hline \multirow[b]{2}{*}{ Holding Period } & \multicolumn{3}{|c|}{$\Delta$ DaysSHORT Mean Value by Tercile } & \multicolumn{2}{|c|}{ Mean Return: 1st Tercile (Buy) } & \multicolumn{2}{|c|}{ Mean Return: 3st Tercile (Sell) } & \multicolumn{2}{|c|}{ 1st Tercile minus 3rd Tercile } \\
\hline & 1st & $3 \mathrm{rd}$ & $\Delta$ & Period & Annualized & Period & Annualized & Period & Annualized \\
\hline$(\mathrm{T}->\mathrm{T}+1)+1$ Month & -0.87 & 1.09 & -1.96 & $0.077 \%$ & $0.923 \% \quad 1$ & $-0.098 \%$ & $-1.176 \% \quad($ & $0.175 \%$ & $2.121 \%$ \\
\hline$(\mathrm{T}->\mathrm{T}+2)+2$ Month & -0.87 & 1.09 & -1.96 & $0.326 \%$ & $1.969 \%$ & $-0.274 \%$ & $-1.632 \%$ & $0.599 \%$ & $3.651 \%$ \\
\hline$(\mathrm{T}->\mathrm{T}+3)+3$ Month & -0.87 & 1.09 & -1.96 & $0.161 \%$ & $0.647 \%$ & $-0.435 \%$ & $-1.730 \%$ & $0.597 \%$ & $2.409 \%$ \\
\hline$(\mathrm{T}->\mathrm{T}+6)+6$ Month & -0.87 & 1.09 & -1.97 & $093 \%$ & $185 \%$ & $41 \%$ & $-0.681 \%$ & $434 \%$ & $0.869 \%$ \\
\hline (T -> T+12) +12 Month & -0.89 & 1.1 & -2.00 & $405 \%$ & 405\% & $81 \%$ & $0.581 \%$ & $-0.176 \%$ & $-0.176 \%$ \\
\hline$(\mathrm{T}+4->\mathrm{T}+5)+1$ Month & -0.88 & 1.09 & -1.97 & $-0.219 \%$ & $-2.601 \%$ & $-0.053 \%$ & $-0.629 \%$ & $-0.167 \%$ & $-1.984 \%$ \\
\hline$(\mathrm{T}+4->\mathrm{T}+6)+2$ Month & -0.87 & 1.09 & -1.97 & $-0.261 \%$ & $-1.557 \%$ & $-0.178 \%$ & $-1.061 \%$ & $-0.084 \%$ & $-0.500 \%$ \\
\hline$(T+4->T+7)+3$ Month & -0.88 & 1.10 & -1.97 & $-0.258 \%$ & $-1.029 \%$ & $0.068 \%$ & $0.273 \%$ & $-0.326 \%$ & $-1.299 \%$ \\
\hline$(T+4->T+10)+6$ Month & -0.88 & 1.11 & -1.99 & $0.373 \%$ & $0.747 \%$ & $-0.008 \%$ & $-0.017 \%$ & $0.381 \%$ & $0.764 \%$ \\
\hline$(\mathrm{T}+4->\mathrm{T}+16)+12$ Month & -0.89 & 1.13 & -2.02 & $0.565 \%$ & $0.565 \%$ & $0.196 \%$ & $0.196 \%$ & $0.368 \%$ & $0.368 \%$ \\
\hline
\end{tabular}

Panel C: Aggregate Fund Net Trades as Multiple of ADTV ( $\triangle$ DaysNET)

$\triangle$ DaysNET Mean Value by Tercile Mean Return: 1st Tercile (Sell) Mean Return: 3st Tercile (Buy) 3rd Tercile minus 1st Tercile

\begin{tabular}{|c|c|c|c|c|c|c|c|c|c|}
\hline \multirow[b]{2}{*}{ Holding Period } & & & & \\
\hline & 1st & 3 rd & $\Delta$ & Period & Annualized & Period & Annualized & Period & Annualized \\
\hline$(\mathrm{T}->\mathrm{T}+1)+1$ Month & -4.43 & 4.15 & -8.58 & $0.023 \%$ & $0.280 \% \quad 1$ & $-0.148 \%$ & $-1.765 \% \quad(\quad$ & $-0.172 \%$ & $-2.040 \% \quad($ \\
\hline$(\mathrm{T}->\mathrm{T}+2)+2$ Month & -4.43 & 4.15 & -8.58 & $0.364 \%$ & $2.207 \%$ & $0.015 \%$ & $0.089 \%$ & $-0.350 \%$ & $-2.079 \%$ \\
\hline ( $\mathrm{T}->\mathrm{T}+3)+3$ Month & -4.43 & 4.15 & -8.59 & $0.656 \%$ & $2.649 \%$ & $0.162 \%$ & $0.650 \%$ & $-0.494 \%$ & $-1.960 \%$ \\
\hline$(\mathrm{T}->\mathrm{T}+6)+6$ Month & -4.44 & 4.16 & -8.60 & $0.160 \%$ & $0.320 \%$ & $0.770 \%$ & $1.547 \%$ & $0.610 \%$ & $1.225 \%$ \\
\hline$(\mathrm{T}->\mathrm{T}+12)+12$ Month & -4.53 & 4.23 & -8.75 & $0.032 \%$ & $0.032 \%$ & $1.179 \%$ & $1.179 \%$ & $1.148 \%$ & $1.148 \%$ \\
\hline$(\mathrm{T}+4->\mathrm{T}+5)+1$ Month & -4.44 & 4.17 & -8.61 & $-0.459 \%$ & $-5.369 \% \quad(\quad)$ & $0.223 \%$ & $2.712 \% \quad($ & $0.682 \%$ & $8.499 \%$ （） \\
\hline$(T+4->T+6)+2$ Month & -4.44 & 4.16 & -8.60 & $-0.793 \%$ & $-4.666 \%(*)$ & $0.602 \%$ & $3.665 \%$ （） & $1.395 \%$ & $8.668 \%(* *)$ \\
\hline$(T+4->T+7)+3$ Month & -4.46 & 4.19 & -8.64 & $-0.820 \%$ & $-3.240 \%$ i j & $0.528 \%$ & $2.130 \% \quad i \quad j$ & $1.348 \%$ & $5.503 \% \quad(*)$ \\
\hline$(T+4->T+10)+6$ Month & -4.48 & 4.22 & -8.70 & $-0.775 \%$ & $-1.544 \%$ & $0.838 \%$ & $1.684 \%$ & $1.613 \%$ & $3.253 \%$ \\
\hline$(\mathrm{T}+4->\mathrm{T}+16)+12$ Month & -4.60 & 4.29 & -8.89 & $-1.202 \%$ & $-1.202 \%$ & $1.482 \%$ & $1.482 \%$ & $2.684 \%$ & $2.684 \%(*)$ \\
\hline
\end{tabular}

Significance:

* 0.05 probability level

** 0.01 probability level

$\star \star \star 0.001$ probability level 
Figure 1: Brazilian Investment Fund Industry: Total Assets Under Management and Number of Investment Funds (December 2000 - June 2019)

Source: ANBIMA (Brazilian Financial and Capital Markets Association)

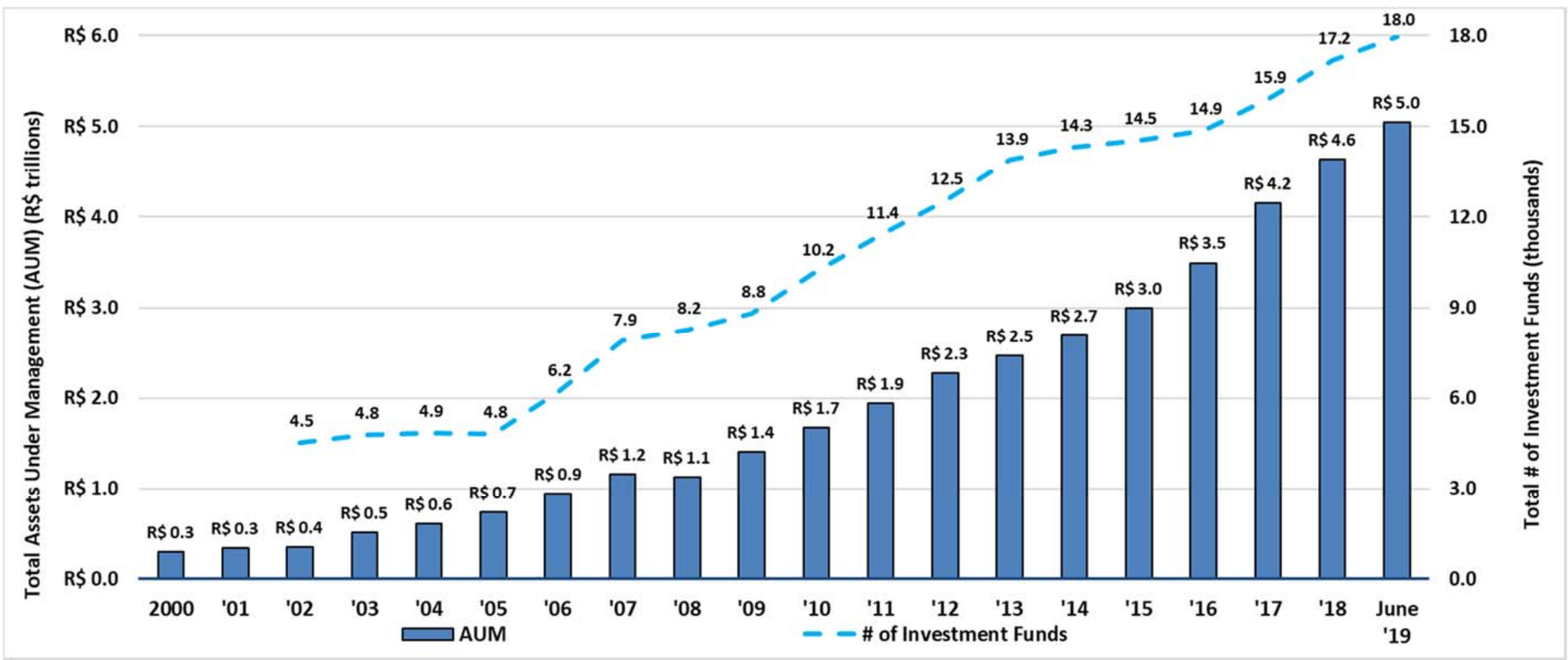


Figure 2: Accumulated Returns Utilizing Fund Holdings as \% of Market Cap. Variables

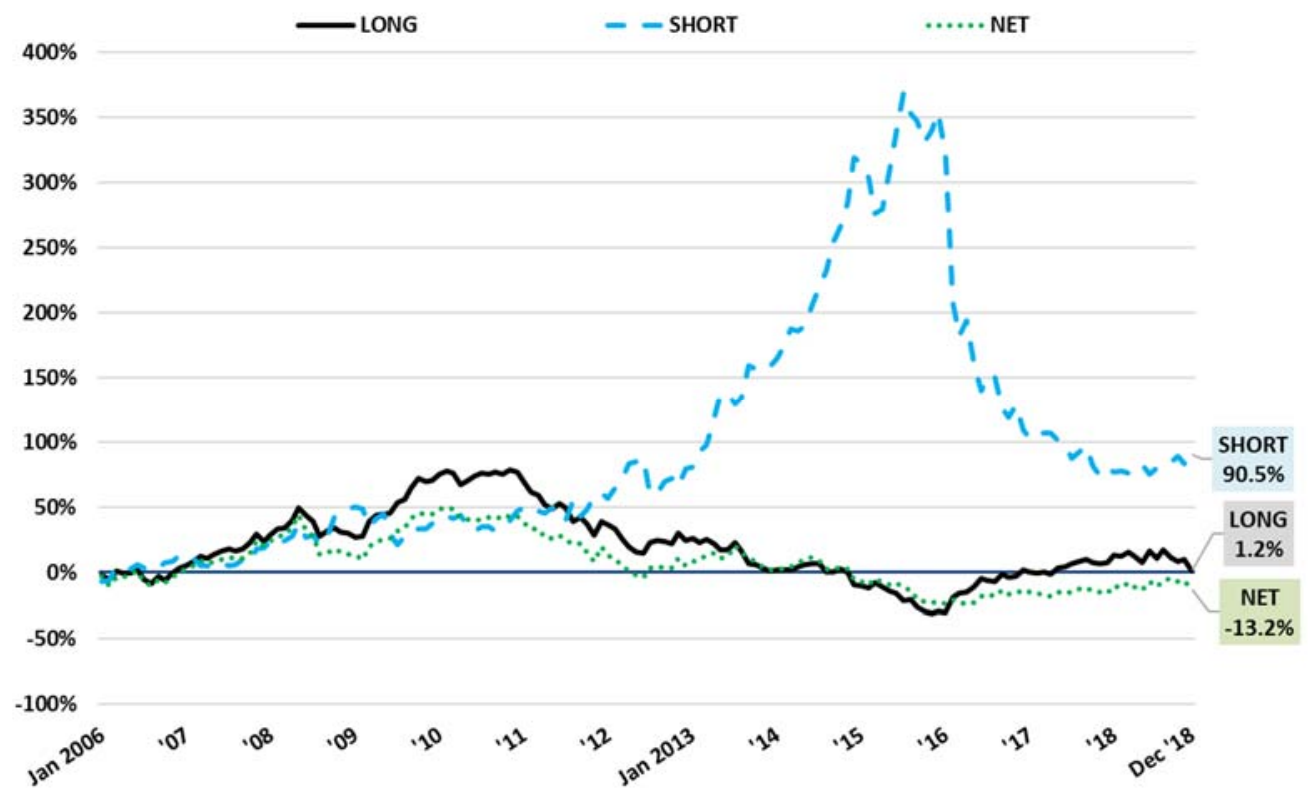

Note:

- Equal-weighted long-short portfolios rebalanced on a monthly-basis. (1-month holding periods)

- Portoflio long (short) components based on $3^{\text {rd }}$ tercile stocks (1 $1^{\text {st }}$ tercile stocks) for the LONG and NET variables.

- Portfolio long (short) components based on $1^{\text {st }}$ tercile stocks ( $3^{\text {rd }}$ tercile stocks) for the SHORT variable. 
Figure 3: Accumulated Returns Utilizing Fund Trades as \% of Market Cap. Variables

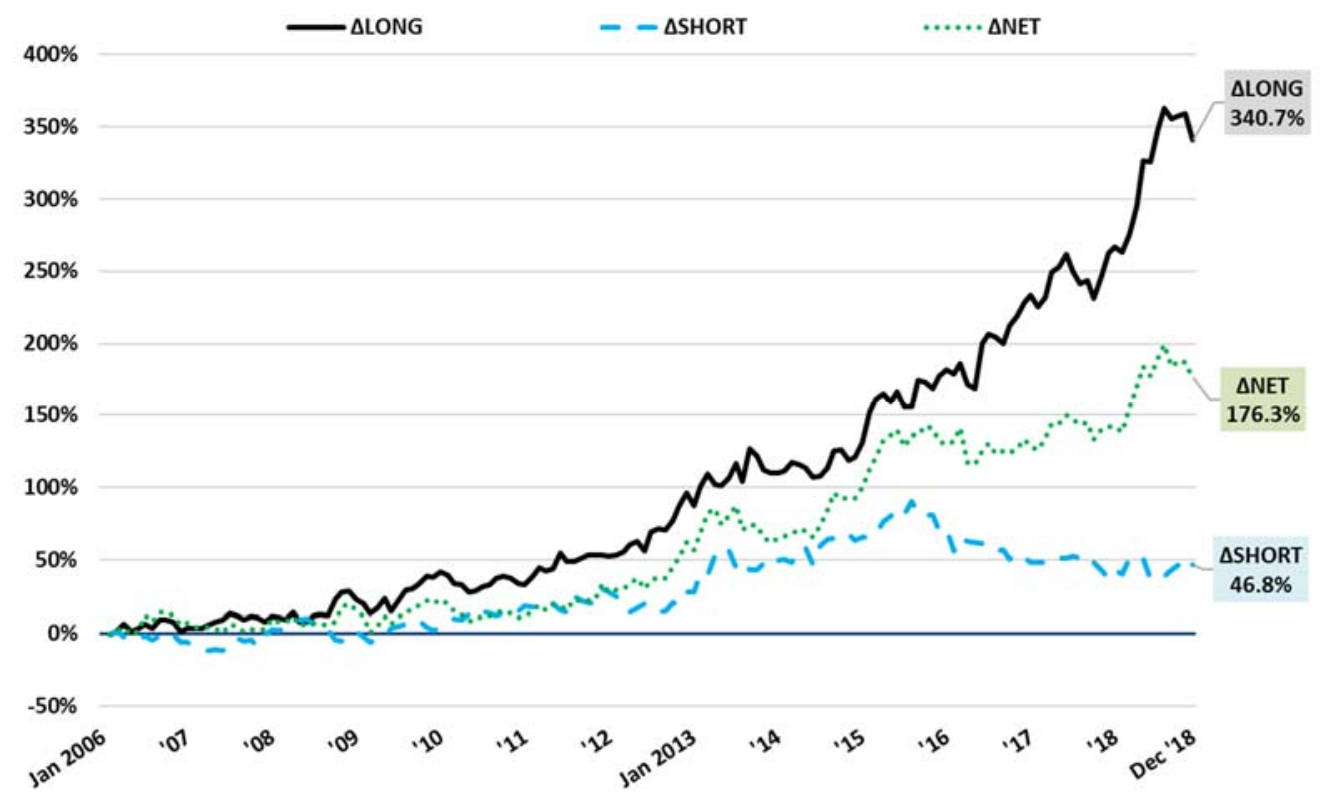

Note:

- Equal-weighted long-short portfolios rebalanced on a monthly-basis. (1-month holding periods)

- Portoflio long (short) components based on $3^{\text {rd }}$ tercile stocks (1 $1^{\text {st }}$ tercile stocks) for the $\triangle L O N G$ and $\triangle N E T$ variables.

- Portfolio long (short) components based on $1^{\text {st }}$ tercile stocks ( $3^{\text {rd }}$ tercile stocks) for the $\triangle S H O R T$ variable. 
Figure 4: Accumulated Returns Utilizing Fund Holdings as Multiple of ADTV Variables

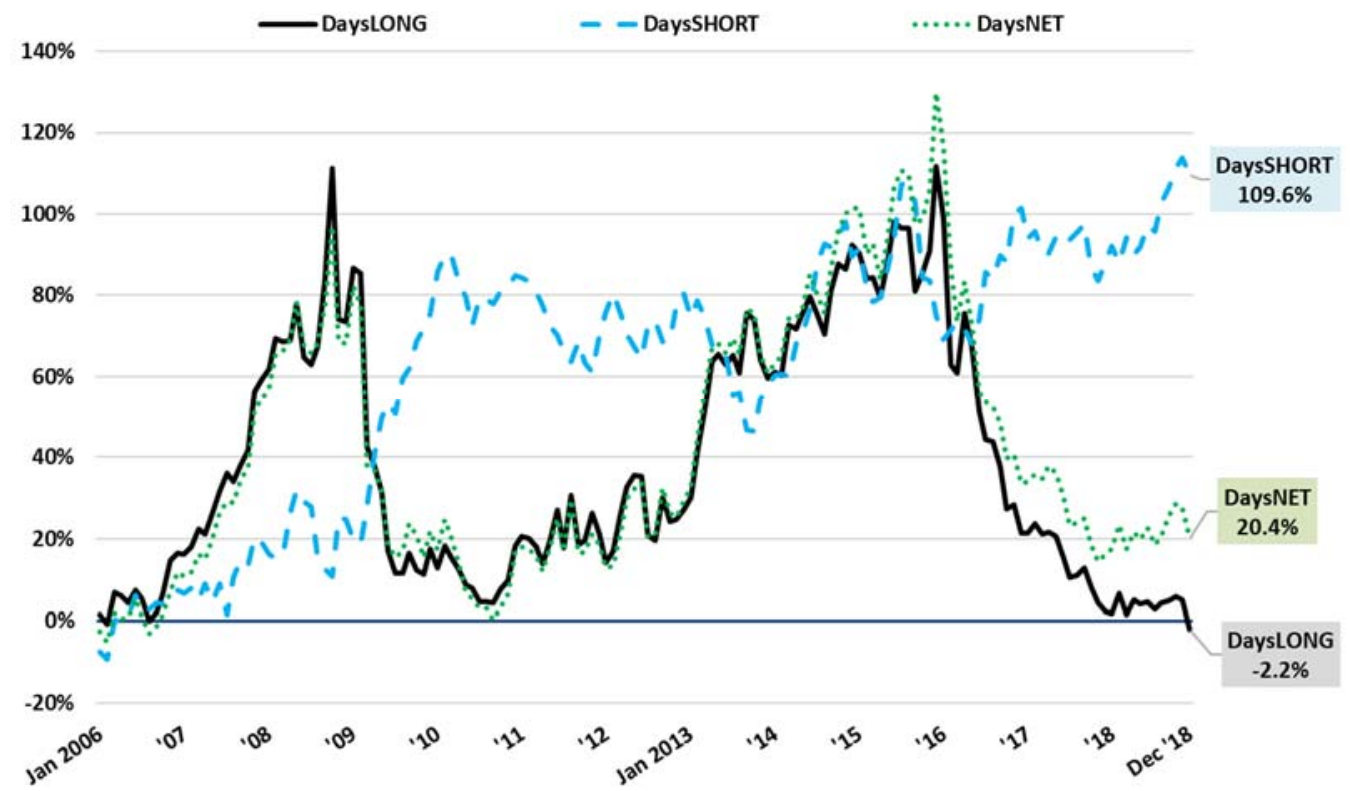

\section{Note:}

- Equal-weighted long-short portfolios rebalanced on a monthly-basis. (1-month holding periods)

- $\quad$ Portoflio long (short) components based on $3^{\text {rd }}$ tercile stocks (1 $1^{\text {st }}$ tercile stocks) for the DaysLONG and DaysNET variables.

- $\quad$ Portfolio long (short) components based on $1^{\text {st }}$ tercile stocks ( $3^{\text {rd }}$ tercile stocks) for the DaysSHORT variable. 
Figure 5: Accumulated Returns Utilizing Fund Trades as Multiple of ADTV Variables

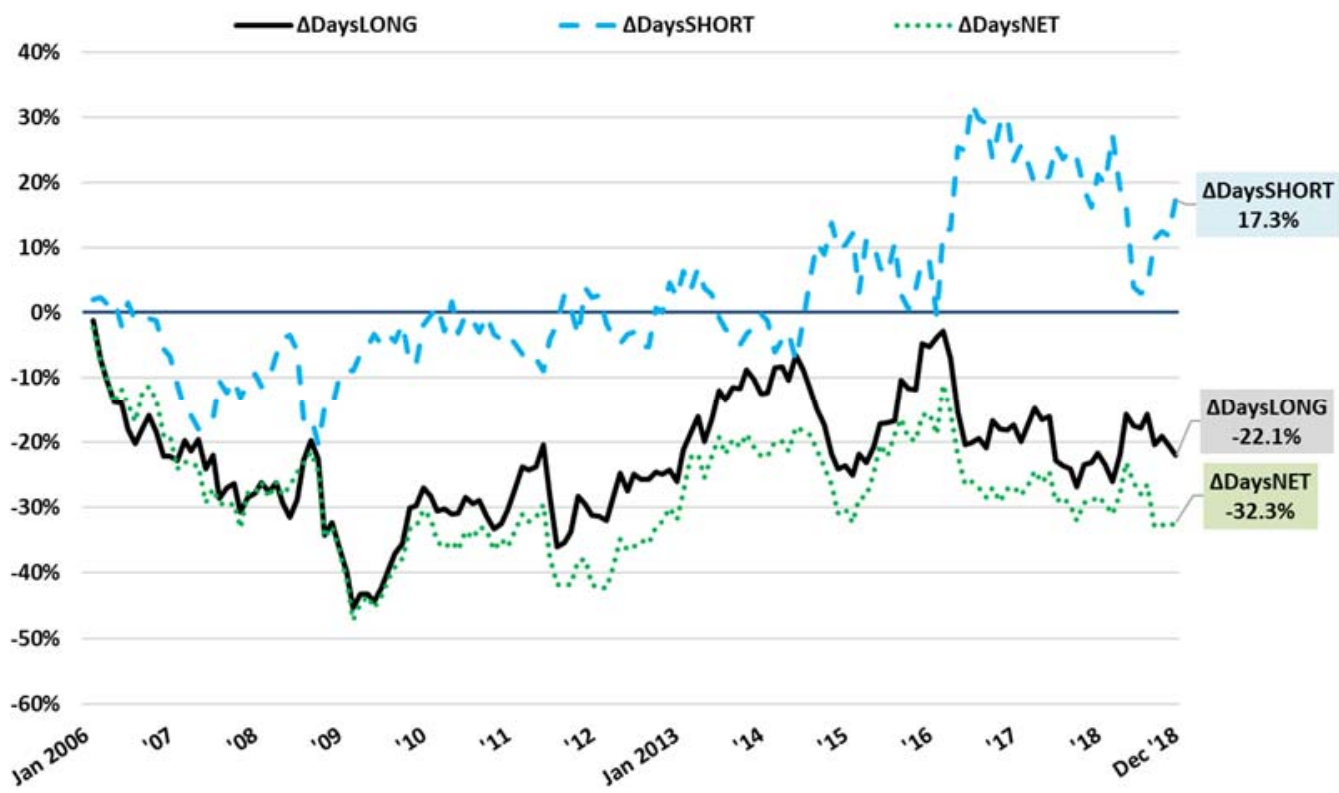

\section{Note:}

- Equal-weighted long-short portfolios rebalanced on a monthly-basis. (1-month holding periods)

- $\quad$ Portoflio long (short) components based on $3^{\text {rd }}$ tercile stocks (1 $1^{\text {st }}$ tercile stocks) for the $\triangle$ DaysLONG and $\triangle$ DaysNET variables.

- $\quad$ Portfolio long (short) components based on $1^{\text {st }}$ tercile stocks ( $3^{\text {rd }}$ tercile stocks) for the $\triangle$ DaysSHORT variable. 